\title{
The international asparagus business in Peru
}

\author{
Jaime de Pablo, Miguel Ángel Giacinti, Valentin Tassile and \\ Luisa Fernanda Saavedra
}

ABSTRACT

A variety of methodologies, such as the Foreign Trade Competitiveness Index, the Foreign Trade Policy Index and the TradeCAN competitiveness matrix, reveal a process of adaptation to changes in world trade in the period from 2002 to 2012, within the context of the so-called "complex adaptive system" as a transition from the fourth to the fifth technological revolution in fresh asparagus exports from Peru. The country's competitiveness map shows that it is not competing globally at the international level but rather partially or regionally. Mexico is its main competitor, with comparative advantages over Peru because of its currency's real exchange rate against the United States dollar, but there are challenges that need to be dealt with in the medium term in this process of adaptation to change. Applied Economics Section.jdepablo@ual.es

Miguel Ángel Giacinti is the head of the Gabinete MAG consultancy (Argentina).

miguel.giacinti@gabinetemag.com

Valentín Tassile is a regular assistant professor at the National University of Comahue (Argentina), Faculty of Agricultural Sciences, Department of Statistics. vtassile@gmail.com

Luisa Fernanda Saavedra is a managing partner at Quality Control Fresh Fruit sAc.1saavedra@qcfreshfruit.com 


\section{I}

\section{Introduction}

Industrial revolutions are associated with the periodizations of Kondratieff long waves, as a number of research studies have pointed out, among them those of Martínez Sánchez (2001) and Jijena (2003). From this theory were subsequently derived the short waves of Kitchin (3 years), Kuznets (5 years) and Juglar (15 years). All these waves concern innovation processes and the introduction of new production areas that drive growth. Kondratieff argues that every technological revolution gives rise to a long economic cycle lasting about 50 years, of which 25 are "boom" years and another 25 "crisis" years. Schumpeter (1935) uses time series to study cyclical crises. In all cases, these are phases of incremental adjustment, improvement or progress in the technologies that drive economic growth.

In particular, the fourth technological revolution in the post-Second World War period saw the greatest wave of construction of organizations for managing world trade. However, the current situation of global economic crisis and the economic recession since 2008 mark the beginning of the fifth technological revolution. This new situation entails a paradigm shift from the fourth revolution, specifically in the following areas: (i) basic resources: from cheap, plentiful energy to adaptable, strategic information and knowledge; (ii) production: from automated to flexible; (iii) product mix: from stable and homogeneous to varied and changing; (iv) skills: from specialization to multiskilling; (v) organizational structure: from hierarchical and departmentalized to horizontal and networked; (vi) labour relations: from conflict resolution to negotiation and cooperation; (vii) markets: from massive and homogeneous to segmented and changing; (viii) competitiveness: from static to dynamic; (ix) management: from costs to management.

It should also be stressed that this fifth revolution is the first to include agriculture in what is considered to be the era of recovering international food prices. Real trade prices have improved steadily since 2000 (by comparison with data from 1961 onward) for soya, wheat, maize, soya oil, roasted coffee, wine, grape must, non-alcoholic beverages, lamb and beef, chicken and pork, fresh fruit and concentrated juices. In the case of vegetables, if garlic, onion, tomato and asparagus are taken for the purposes of analysis, there was a decline in real prices that bottomed out in 2000, and the current situation is one of stability with no price recovery for the time being.

This phenomenon means that agriculture will once again be strategically crucial to the countries' economic and social development over the coming decades. People migrated from the countryside to large cities because of cheap food, as did young people in consequence of the generational changeover problem. But now the process is almost certain to go into reverse, with people moving to cities close to where production takes place, and even the availability of wage income for non-food consumption will change, with repercussions for other sectors.

In this context, the key questions are these. Are there going to be shifts in agricultural markets in the coming years, aside from real price recovery in some sectors? And will this be the case in particular with the trade in asparagus, as a non-traditional product in Latin America?

Answering the second question is the purpose of this article, which particularly analyses the model adopted in Peru and its process of adaptation to change, since it is the world's leading exporter of asparagus.

Section II deals with the global trade in asparagus, looking at exports and imports. Section III presents a competitiveness map based on the Foreign Trade Competitiveness Index (FTCI). Section IV discusses the sector's evolution in terms of production, exchange rates, the structure of trade and company policies. Lastly, section $\mathrm{V}$ provides the main conclusions. 


\section{II}

\section{The global asparagus trade}

\section{Exports}

Fresh asparagus exports generate revenues of US\$ 1.027 billion a year, with a volume of 343,000 tons. Average annual sales growth in 2003-2012 was 7.7\% in dollar terms, while volume increased by $5 \%$ a year on average, which explains why the free on board (FOB) export price increased by only $2.3 \%$ a year in the period analysed. Peru is the world's largest exporter, registering $6.7 \%$ annual growth in foreign sales by volume and $11 \%$ by value.

In 2000, worldwide export shares were as follows: Peru: $33.1 \%$; Mexico: 22.3\%; United States: 15\%; Netherlands: $8.4 \%$; Spain: $4.5 \%$; Germany: $2.1 \%$; Italy: $2.1 \%$; Greece: $2 \%$; France: $2 \%$; Australia: $1.7 \%$; Thailand: $1.2 \%$; Poland: $0.9 \%$; Hungary: $0.9 \%$ (see table 1).

Some $60 \%$ of world asparagus exports in 2012 took place from January to June, with the remaining $40 \%$ taking place from July to December. When a country exports outside of its own production calendar, it usually sells asparagus previously imported from other countries.

At the country level, the following distinctions can be made regarding the seasonality of production, and they explain why the exportable global supply is what it is: (i) Peru and Thailand are the only countries that produce all year round; (ii) the United States produces from January to September; (iii) Spain produces from January to July and France and Portugal from March to July; (iv) Germany and the Netherlands produce from August to November; (v) China produces in two periods, from February to July and from September to December; (vi) Canada produces in May and June; (vii) Mexico produces in two periods, from January to April and from June to October; (viii) Ecuador produces from June to February; (ix) Chile produces from July to December; (x) New Zealand produces from September to December; (xi) Australia produces from September to November.

\section{Imports}

Fresh asparagus imports cost the importing countries a total of US\$ 1.2 billion a year, with a volume of 343,000 tons.

Taking the annual rate as given by the table 2 data and using the linear adjustment trend slope calculation

TABLE 1

Fresh asparagus exports worldwide, by value, 2003-2012

(Thousands of dollars)

\begin{tabular}{lrrrrrrrrrr}
\hline Country & \multicolumn{1}{c}{2003} & \multicolumn{1}{c}{2004} & \multicolumn{1}{c}{2005} & \multicolumn{1}{c}{2006} & 2007 & 2008 & 2009 & \multicolumn{1}{c}{2010} & 2011 & 2012 \\
\hline Total & 497848 & 550831 & 602971 & 663382 & 709361 & 738116 & 761765 & 902963 & 955879 & 1026809 \\
Peru & 108343 & 141545 & 160015 & 187364 & 235701 & 230427 & 250823 & 290684 & 291828 & 339987 \\
Mexico & 77357 & 78508 & 114044 & 129094 & 116553 & 101582 & 146209 & 217413 & 229822 & 228767 \\
United States & 69137 & 70527 & 81075 & 79611 & 81719 & 95178 & 101241 & 128861 & 140148 & 153955 \\
Netherlands & 28186 & 35627 & 32148 & 38325 & 53338 & 65113 & 59867 & 56014 & 70807 & 86343 \\
Spain & 77869 & 70908 & 59130 & 64391 & 51677 & 51731 & 47109 & 40771 & 47146 & 46508 \\
Greece & 29861 & 33029 & 31273 & 38932 & 43665 & 50289 & 32793 & 39051 & 22835 & 20260 \\
Thailand & 15625 & 24532 & 28093 & 26266 & 23601 & 23406 & 17540 & 12974 & 15618 & 12042 \\
Germany & 4590 & 5126 & 7274 & 8825 & 9482 & 11958 & 10934 & 16698 & 21409 & 21954 \\
Italy & 2315 & 2829 & 4072 & 4569 & 7788 & 12778 & 9902 & 13949 & 16192 & 21787 \\
France & 27517 & 22829 & 20037 & 22843 & 19012 & 17548 & 19630 & 16477 & 20639 & 20470 \\
Australia & 14579 & 19661 & 16969 & 13562 & 13802 & 20538 & 11887 & 15822 & 16842 & 17029 \\
Poland & 3076 & 4087 & 3396 & 3521 & 2906 & 3716 & 5567 & 7027 & 9145 & 9389 \\
Hungary & 5392 & 6355 & 5366 & 5854 & 7390 & 11797 & 10391 & 9971 & 7847 & 9678 \\
Other countries & 34001 & 35268 & 40079 & 40225 & 42727 & 42055 & 37872 & 37251 & 45601 & 38640 \\
\hline
\end{tabular}

Source: prepared by the authors on the basis of data from the International Trade Centre (ITC) and the United Nations Commodity Trade Statistics Database (COMTRADE). 


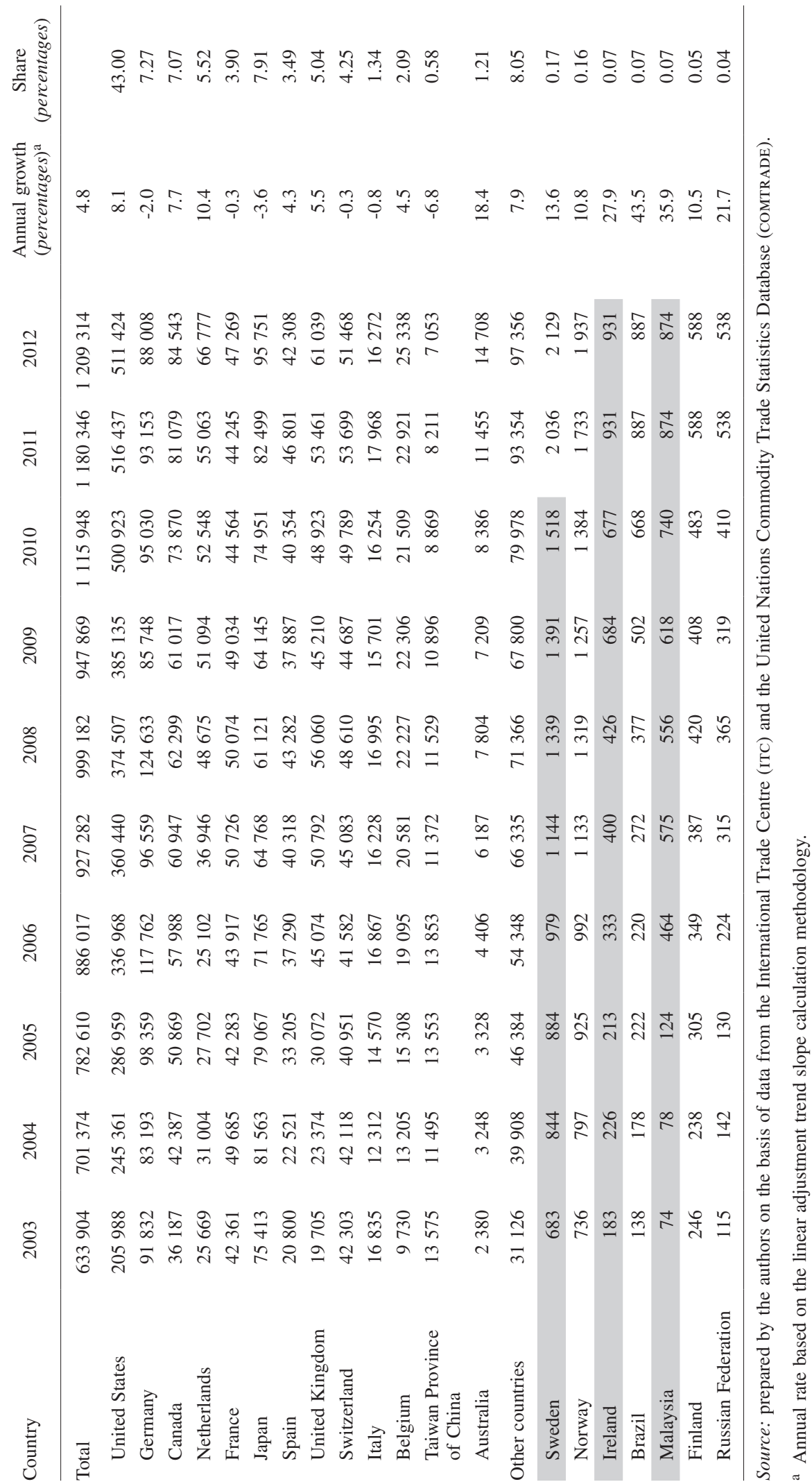


methodology, worldwide trade grew by $4.8 \%$ a year from 2003 to 2012, while the importing countries with above-average growth rates were Brazil (43.5\%), Malaysia (35.9\%), Ireland (27.9\%), the Russian Federation (21.7\%), Australia (18.4\%), Sweden (13.6\%), Norway (10.8\%), Finland (10.5\%), the Netherlands (10.4\%), Canada (7.7\%) and the United Kingdom (5.5\%).
Major importers whose purchases tended to tail off were Italy, Germany and Japan. The largest buyers were the United States (42.3\% of the total), Japan (7.9\%), Germany (7.3\%), Canada (7\%), Netherlands (5.5\%), the United Kingdom (5\%), Switzerland (4.3\%), France (3.9\%), Spain (3.5\%), Belgium (2.1\%), Italy (1.3\%), Australia $(1.2 \%)$ and Taiwan Province of China (0.6\%).

\section{III}

\section{Competitiveness map}

\section{Foreign Trade Competitiveness Index (FTCI)}

At present, the only universally accepted concept of competitiveness is the economicist one developed by the World Economic Forum and used to develop the country-level Global Competitiveness Index. This index measures a set of institutions, policies and factors that determine what levels of economic prosperity are sustainable at the present time and in the medium run. There is in fact a wide range of definitions of sectoral or corporate competitiveness, but the most appropriate one for international trade from the vantage point of this study is the ability to keep or expand market share while simultaneously raising the living standards of the population associated with the production area. On the basis of this definition, a useful tool is the Foreign Trade Competitiveness Index (FTCI), which takes as its numerator "market share" in the countries that are major importers of a particular product and as its denominator the exporting country's global "export share" for that product.

Formula: $\quad \mathrm{FTCI}=\left(M_{k i j} / M_{k j}\right) /\left(X_{k i} / X_{k w}\right)$

where:

$\mathrm{M}_{k i j}$ Imports of product $k$ from country $i$ by country $j$

$\mathbf{M}_{k j} \quad$ Total imports of product $k$ by country $j$

$\mathrm{X}_{k i} \quad$ Exports of $k$ by country $i$

$\mathrm{X}_{k w} \quad$ Worldwide $(w)$ exports of product $k$

The data are for monetary turnover rather than volume, on the basis that this is more relevant as an indicator of competitiveness because it incorporates the value added to the product analysed into the study. A higher share in a particular international market than in worldwide exports can be taken to denote greater competitiveness because the market share is greater than the worldwide share, and vice versa if it is lower.

Carrying out an analysis that combines the FTCI and the trend of market share (because this is an effect rather than a cause variable) is an effective way of obtaining a "global competitiveness map" for a product in a country while also making it easier to visualize the trend in major markets under the trade complexity and adaptability paradigm. This implies a larger number of importing countries, with the peculiarity of continuous changes in competition between international suppliers owing to shifts in market share arising from alterations in trade policy (price, volume or both) in one or another of them.

In the construction of the "competitiveness map", the horizontal axis is the originating country's market share in each of the main importing countries relative to its mean worldwide market share for the product analysed, while the vertical axis compares the trend of market share over a given period, with the size of the circle, which represents annual dollar turnover, showing how great this is (see figure 1).

This methodology is efficient, because access to international trade data is not expensive, and effective, because it fulfils the purpose it was created for. It has been used to analyse fruits such as kiwi (De Pablo and Giacinti, 2012a), pears (De Pablo and Giacinti, 2012b; De Pablo, Giacinti and Uribe, 2012), apples (De Pablo and Giacinti, 2012c) and lemons (De Pablo and Giacinti, 2013).

\section{Findings}

Peru is tending to diversify its international asparagus trade (see figure 1), but its main customer is still the United States market, which its asparagus enters at a $0 \%$ tariff rate and which accounts for $60.58 \%$ of sales. 
FIGURE 1

Peru: asparagus export competitiveness map, 2003-2011

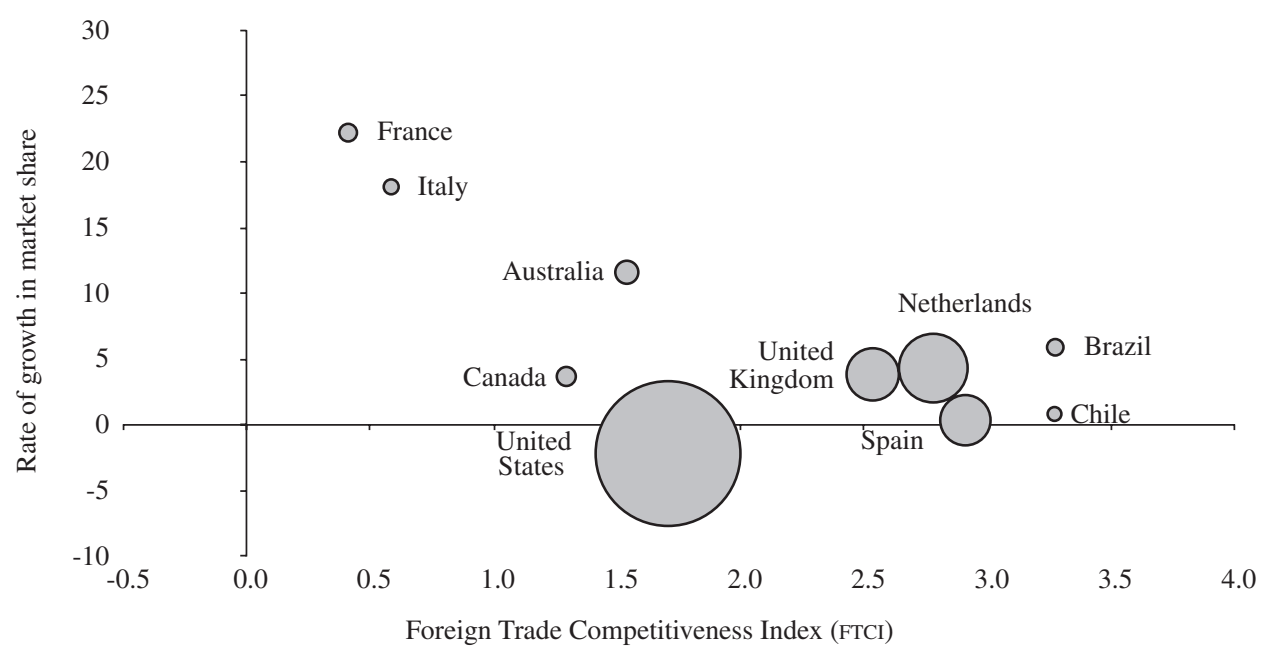

Source: prepared by the authors on the basis of table 3 data.

Note: circle size indicates value of exports in 2011.

Sales in the Netherlands (13.62\%), the United Kingdom $(7.89 \%)$ and Spain $(7.32 \%)$ are also substantial.

Table 3 shows that the highest values of the Foreign Trade Competitiveness Index (FTCI) are now found in Brazil (3.28), Spain (2.91), the Netherlands (2.78) and the United Kingdom (2.54), while the value for the United States is 1.70. It can also be seen that only the United States presents negative values for the average annual rate of change in market share $(2.2 \%)$, while the highest values are in Japan (34.5\%), France (22.3\%), Italy $(18.1 \%)$ and Australia (11.6\%). Indeed, there are countries where market share is higher than in the United States (with strong competition from Mexico), such as the United Kingdom, the Netherlands, Spain, Chile and Brazil.

The changes observed in the countries importing Peruvian asparagus bear out the new paradigm of dynamic competitiveness, as this is not global but presents peculiarities in its rate of growth in each market.

It is striking that Germany (see table 2), the country with the highest per capita consumption and the world's second-largest importer, is not directly a customer of Peru. The explanation is that the Netherlands, as with other fruits and vegetables, acts as a broker, carrying out trade triangulation with European markets whose commercialization costs are higher. Although Japan and the United States are the other great global consumers of asparagus, the latter is Peru's main customer while
TABLE 3

Peru: asparagus trade indicators, 2011

\begin{tabular}{lccc}
\hline Importer & FTCI & $\begin{array}{c}\text { Annual change in } \\
\text { market share } \\
\text { (percentages) }\end{array}$ & $\begin{array}{c}\text { Exports } \\
\text { (thousands of } \\
\text { dollars) }\end{array}$ \\
\hline United States & 1.70 & -2.2 & 176790 \\
Netherlands & 2.78 & 4.4 & 39749 \\
United Kingdom & 2.54 & 3.9 & 23037 \\
Spain & 2.91 & 0.4 & 21348 \\
Japan & 0.49 & 34.5 & 4651 \\
Australia & 1.54 & 11.6 & 4471 \\
Canada & 1.29 & 3.6 & 3046 \\
France & 0.41 & 22.3 & 2621 \\
Brazil & 3.28 & 6.0 & 2276 \\
Italy & 0.58 & 18.1 & 1878 \\
Chile & 3.27 & 0.8 & 1602 \\
\hline
\end{tabular}

Source: Fruit and Vegetable Information Centre, "Business Intelligence" [online] 410http://www.cif-businessintelligence.com/ eng/index.html, and United Nations Commodity Trade Statistics Database (COMTRADE).

FTCI: Foreign Trade Competitiveness Index.

Japan is currently marginal; in the years covered by this study, however, its purchases increased very substantially. These observations also reveal that the management paradigm has not been developed to its fullest extent in the Peruvian asparagus trade to adapt it to the whole of the market potential that exists. 


\section{IV}

\section{The evolution of the sector}

\section{Production}

The main production areas in Peru lie on the coast, in the departments of La Libertad, Ica and Lima.

White asparagus is planted along the northern coast, especially in the vicinity of Trujillo, and green asparagus is grown between Lima and the southern city of Arequipa. According to official data, average annual growth in the land area planted with asparagus in Peru was $8.9 \%$ in 2004-2011, with a total of somewhat over 30,000 hectares in the latter year. The increase in the exportable supply from 2004 to 2011 was due to the increase in growing area (from 18,900 to 30,000 hectares) and technological improvements, with an initial stage of good international prices (Illescas and Jaramillo, 2011). At the fifth International Asparagus Congress, held in
Peru in 2010, it was stated that the business accounted directly and indirectly for 120,000 rural jobs. ${ }^{1}$

In 2004-2012 (see table 4), total Peruvian asparagus exports grew at an average annual rate of $5.6 \%$ by volume, with exports of tinned asparagus increasing by $3.2 \%$ a year and those of fresh or refrigerated asparagus by $6.9 \%$. There was also a drop in asparagus production that resulted in lower sales abroad in 2012, owing to climatic factors and agricultural conditions in old plantations, which have switched to other crops owing to difficulties in earning a return in the asparagus sector because of rising domestic costs in dollar terms.

1 See [online] http://www.exportando-peru.com/tips-detalle.php?id noticia $=603 \&$ idcategoria $=9$.

TABLE 4

Peru: total asparagus exports, 2004-2012

(Tons)

\begin{tabular}{|c|c|c|c|c|c|c|c|c|c|c|}
\hline Detail & 2004 & 2005 & 2006 & 2007 & 2008 & 2009 & 2010 & 2011 & 2012 & $\begin{array}{l}\text { Annual growth } \\
\text { (percentages) }^{\mathrm{a}}\end{array}$ \\
\hline Total exported & 112247 & 121007 & 137857 & 154222 & 167422 & 163928 & 173945 & 197074 & 173497 & 5.6 \\
\hline Tinned & 40184 & 41353 & 45448 & 58598 & 63563 & 49837 & 47070 & 60757 & 53816 & 3.2 \\
\hline Fresh & 72063 & 79654 & 92409 & 95624 & 103859 & 114091 & 126875 & 136317 & 119681 & 6.9 \\
\hline
\end{tabular}

Source: prepared by the authors on the basis of data from the Office of the National Superintendent of Customs and Tax Administration (SUnAT) of Peru.

a Annual rate based on the linear adjustment trend slope calculation methodology.

Peru is the world's largest exporter of fresh or refrigerated asparagus, but the second-largest for tinned asparagus, although in 2012 it pulled just ahead of China in volume and was the global leader. Exports of tinned asparagus have expanded since the late 1980s, although they tended to level off in the mid-1990s. Fresh and tinned asparagus is Peru's second-largest agricultural export after coffee.

If the trade is measured by annual dollar turnover, Peru has consistently been the world's largest seller of tinned asparagus since 2004. The main destinations for this are European countries (see table 5), while the main market for fresh asparagus is the United States (see table 6).
Although supplies are available in every month of the year, the main production and trade window is from July to December (Benson, 2012). These months have accounted for $68 \%$ of the total in recent years, with $85 \%$ of fresh or refrigerated asparagus exports being sent by air; this compares with a figure of $80 \%$ in the 2004-2012 period, when there was a low of $70 \%$ and a high of $91 \%$.

This growth process was heavily influenced by policy changes, as manifested in legislation that set no limits on the size of agricultural holdings; established the same rights and obligations for local and foreign owners; promoted development by reducing the $15 \%$ company profits tax; and provided regional incentives in the form of a 15-year tax exemption for those investing in special 
TABLE 5

Peru: exports of tinned asparagus, 2004-2012

(Tons)

\begin{tabular}{|c|c|c|c|c|c|c|c|c|c|}
\hline Market & 2004 & 2005 & 2006 & 2007 & 2008 & 2009 & 2010 & 2011 & 2012 \\
\hline Africa & 0 & 0 & 0 & 0 & 0 & 308 & 50 & 0 & 113 \\
\hline Asia & 1636 & 1491 & 1133 & 1019 & 1339 & 1306 & 1433 & 1458 & 1688 \\
\hline Europe & 32989 & 29962 & 31126 & 44405 & 43117 & 35116 & 35166 & 45269 & 37114 \\
\hline Latin America & 421 & 440 & 822 & 912 & 921 & 849 & 966 & 1223 & 1446 \\
\hline MERCOSUR & 0 & 9 & 0 & 11 & 11 & 2 & 0 & 2 & 11 \\
\hline North America & 5137 & 9451 & 12366 & 12252 & 18176 & 12255 & 9456 & 12805 & 13445 \\
\hline Russian Federation & 0 & 0 & 0 & 0 & 0 & 0 & 0 & 0 & 0 \\
\hline Grand total & 40184 & 41353 & 45448 & 58598 & 63563 & 49837 & 47070 & 60757 & 53816 \\
\hline
\end{tabular}

Source: prepared by the authors on the basis of data from the Office of the National Superintendent of Customs and Tax Administration (SUNAT) of Peru.

TABLE 6

Peru: exports of fresh or refrigerated asparagus, 2004-2012

(Tons)

\begin{tabular}{|c|c|c|c|c|c|c|c|c|c|}
\hline Market & 2004 & 2005 & 2006 & 2007 & 2008 & 2009 & 2010 & 2011 & 2012 \\
\hline Africa & 0 & 45 & 96 & 106 & 81 & 66 & 105 & 146 & 133 \\
\hline Asia & 624 & 1017 & 1662 & 1558 & 1400 & 2174 & 3167 & 3294 & 3553 \\
\hline Europe & 15277 & 18692 & 21485 & 22342 & 25745 & 28499 & 32098 & 33738 & 33310 \\
\hline Latin America & 191 & 265 & 465 & 458 & 341 & 528 & 723 & 1083 & 855 \\
\hline Middle East & 11 & 3 & 7 & 8 & 2 & 7 & 13 & 44 & 57 \\
\hline MERCOSUR & 164 & 244 & 400 & 571 & 741 & 902 & 1216 & 1528 & 1915 \\
\hline North America & 55796 & 59373 & 68283 & 70582 & 75544 & 81915 & 89549 & 96485 & 79855 \\
\hline Russian Federation & 0 & 15 & 11 & 0 & 6 & 0 & 3 & 0 & 2 \\
\hline Grand total & 72063 & 79654 & 92409 & 95624 & 103859 & 114091 & 126875 & 136317 & 119681 \\
\hline
\end{tabular}

Source: prepared by the authors on the basis of data from the Office of the National Superintendent of Customs and Tax Administration (SUnat) of Peru.

export zones and in basic crop irrigation infrastructure, one example being the Chavimochic project in the department of La Libertad. The creation of the Ministry of Foreign Trade and Tourism was also a public policy milestone, not only because it pursues trade agreements with other countries, but also because it operates the Commission for the Promotion of Peruvian Exports and Tourism (PromPeru), the National Strategic Exports Plan (PENX) and the Foreign Trade Single Window (VUCE).

\section{The exchange rate}

A macroeconomic factor affecting the profitability of asparagus growing and exporting in Peru is the exchange rate of its currency against the United States dollar. The Economic Research Service of the United States Department of Agriculture prepares statistics on the evolution of both real and nominal exchange rates for many countries. Figure 2 shows that the Nuevo Sol has been strengthened so that dollar costs have been rising, while the Mexican currency tended to weaken up to 2012, reducing local costs in dollars. This means that more technology needs to be incorporated into the whole Peruvian asparagus chain, including logistics and commercialization as well as production and packing, and management needs to be optimized to improve the economic performance of the sector.

\section{The trade structure}

(a) The Herfindahl-Hirschman Index (HHI)

The HHI is used to analyse changes in the structure of world trade over and above real price movements, and is the only legally regulated tool for those in the 


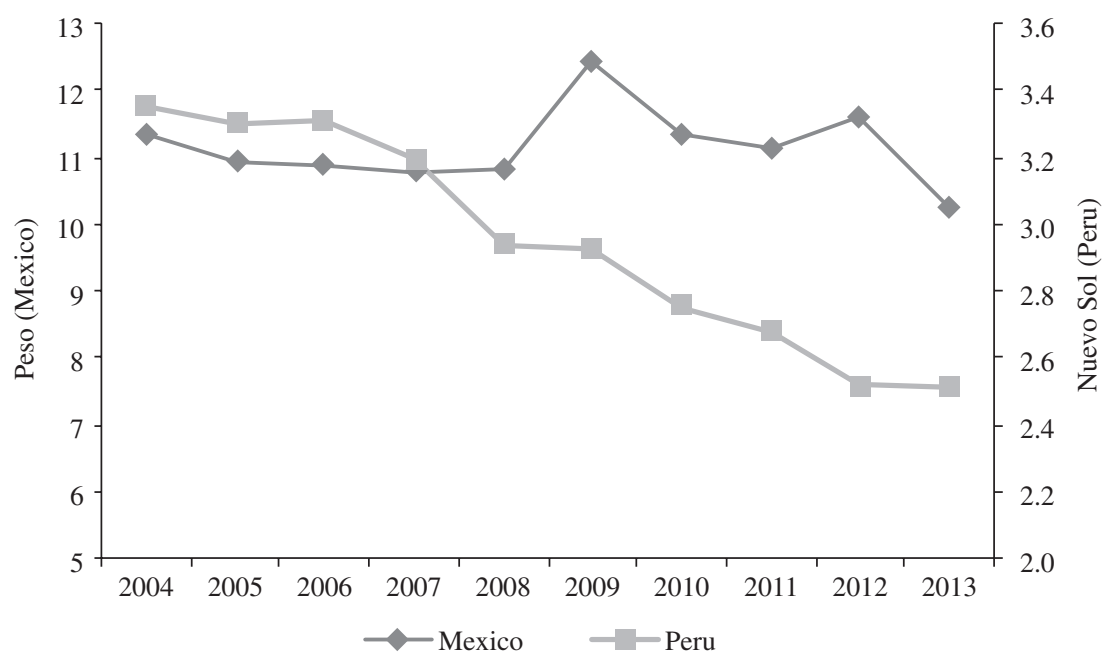

Source: Mathew Shane, United States Department of Agriculture [online] http://www.ers.usda.gov/ers-staff-directory/mathew-shane.aspx\#. UsLYY9JDuSo.

European Union, the United States ${ }^{2}$ and elsewhere, as some studies have noted (Sawaya Jank, Paes Leme and Meloni Nassar, 2001; Mariscal and Rivera, 2007; Durán Lima and Álvarez, 2008; Baumann, 2009; Alarco and del Hierro, 2010; Petit, 2012; Caputi Lélis, Moreira Cunha and Gomes de Lima, 2012; Fadzlan and Muzafar, 2013). Some authors have also analysed the issue of whether the HHI is effective or requires adjustments (Hirschman, 1964; Djolov, 2011).

This index measures the market concentration, taking account of both the number of competitors and their market shares, and is calculated as the square of the sum of the percentage share of the $i$-th firm in the industry. The calculation is expressed in the following formula:

$$
\mathrm{HHI}=\sum_{\mathrm{i}=1}^{\mathrm{n}}\left(\frac{X_{i}}{X} 100\right)^{2}
$$

where:

$\frac{X_{i}}{X} \quad$ share of the $i$-th firm in the market

(n) number of firms in the industry

\footnotetext{
2 See [online] http://www.justice.gov/atr/public/testimony/hhi.htm.
}

The scale used in the United States is as follows: (i) $\mathrm{HHI}<1,000$ represents a low level of concentration, (ii) $1,000<\mathrm{HHI}<1,800$ represents a moderate level of concentration and (iii) $\mathrm{HHI}>1,800$ represents a high level of concentration.

European Union rules are the same except that a score has to be over 2,000 points for economic concentration to be considered high.

To compare data across countries or analyse some explanation for the evolution of the $\mathrm{HHI}$ in a time series, it is valid for the data to be normalized to remove the effects of aggregating the number of firms (Baumann, 2009). This entails a new index in percentage terms, solely for the purposes of comparison or analysis, with the following formula in the present case:

$$
\frac{\sqrt{H H I}-\left(100 * \sqrt{\frac{1}{n}}\right)}{100 *\left(1-\sqrt{\frac{1}{n}}\right)}
$$

(b) Market concentration

The structure of the Peruvian export model for fresh asparagus is one of low concentration (below 1,000 points on the HHI scale), with an increasing trend towards lower levels, given that there was an annual decrease of $4.3 \%$ in $2002-2012$ (see table 7). 
Peru: Herfindahl-Hirschman Index for exports of fresh asparagus, 2002-2012

\begin{tabular}{|c|c|c|c|c|c|c|c|c|c|c|c|c|}
\hline Market & 2002 & 2003 & 2004 & 2005 & 2006 & 2007 & 2008 & 2009 & 2010 & 2011 & 2012 & $\begin{array}{l}\text { Annual growth } \\
\text { (percentages) }\end{array}$ \\
\hline \multicolumn{13}{|l|}{ Export HHI } \\
\hline Average & 687 & 563 & 488 & 476 & 463 & 427 & 380 & 384 & 380 & 419 & 420 & -4.3 \\
\hline North America & 751 & 599 & 391 & 315 & 293 & 300 & 297 & 332 & 369 & 410 & 347 & -5.5 \\
\hline Europe & 1209 & 1350 & 1139 & 1247 & 1133 & 1032 & 753 & 742 & 714 & 731 & 860 & -5.5 \\
\hline Latin America & 4266 & 3207 & 4087 & 4786 & 5489 & 3542 & 3869 & 2779 & 2326 & 2635 & 1715 & -5.8 \\
\hline MERCOSUR & 4374 & 3025 & 1677 & 2676 & 5231 & 4768 & 1513 & 1450 & 1172 & 1557 & 1364 & -8.7 \\
\hline Asia & 10000 & 7279 & 9019 & 6712 & 4707 & 5047 & 2386 & 1465 & 1437 & 1556 & 1707 & -19.7 \\
\hline Africa & & & & 8238 & 9319 & 9711 & 9399 & 4087 & 5680 & 9057 & 8361 & -2.3 \\
\hline Middle East & & & & 5159 & 10000 & 9949 & 10000 & 6172 & 3987 & 4546 & 3101 & -10.0 \\
\hline
\end{tabular}

Source: prepared by the authors on the basis of data from the Office of the National Superintendent of Customs and Tax Administration (sUNAT) of Peru.

The market accounting for the largest volume of trade, such as North America and Europe, present low concentration, while smaller markets currently present moderate concentration (Latin America, MERCOSUR and Asia) and high concentration (Africa and the Middle East).

The records of those importing by sea, analysed using the HHI, project a structure of lower trade concentration (see table 8); it should be noted that maritime exports fell in 2012 because of a smaller harvest, which explains the rise in the index relative to 2011. The bulk of asparagus exports goes by air, but records for this form of transport, unlike sea transport, were not available. In this case, the data indicate low concentration in the North American market (the main destination for Peruvian asparagus), unlike the Latin American market, where concentration is moderate, and the European and Asian markets, where it is high.

TABLE 8

Peru: Herfindahl-Hirschman Index for seaborne imports of fresh asparagus, 2011-2012

\begin{tabular}{lrr}
\hline Market & 2011 & 2012 \\
\hline Import HHI & & \\
Average & 489 & 840 \\
North America & 816 & 962 \\
Europe & 1510 & 2304 \\
Latin America & 1606 & 1449 \\
Asia & 7091 & 7883 \\
\hline
\end{tabular}

Source: prepared by the authors on the basis of data from Fresh Cargo [online] http://www.qcfreshfruit.com/.

The rise in the number of exporting firms from 60 in 2002 to 99 in 2012 (see table 9) is one of the factors accounting for the decline in the economic concentration of the sector in general, as well as the market shares of the main exporters. Some firms have begun a process of sales diversification and are growing and exporting less asparagus, but increasing their supply of other products, such as avocado, table grapes or blueberries for the European, Latin American, Asian and North American markets. The change in their market share within the larger firms category and the increase in the number of exporters account for the decline in economic concentration. In MERCOSUR and the Middle East, there has been no sales diversification or decline in the export volumes of the largest firms, which include the Beta Agroindustrial Complex, Damper Trujillo, Agrícola la Venta and Agro Paracas, and only the growth in new exporters explains the drop in economic concentration. As a result, the normalized HHI is positive (see table 10) whereas in the markets the normalized HHI is negative because, alongside growth in the number of exporters, large firms have reduced the intensity of their asparagus sales to offer other produce in their trade portfolios.

The effects of the continued strengthening of the local currency in real terms since 2010 (see figure 2) have been a drop in the number of firms from 123 in 2009 to 99 in 2012 (see table 9) and, consequently, a slight upward trend in the HHI in the last few years (see table 7), although it remains within the lower economic concentration level of the scale.

The atomization of the trade structure of Peruvian asparagus because of reduced economic concentration (more firms and declining market shares for the biggest traders) would appear to be a new paradigm of the fifth technological revolution. The same phenomenon as regards the level of economic concentration in the structure of exporters and importers can also be seen in Chile's foreign trade in fruit, on which a case study will shortly 
TABLE 9

Peru: number of firms exporting fresh asparagus, by trade region, 2002-2012

\begin{tabular}{|c|c|c|c|c|c|c|c|c|c|c|c|c|}
\hline Market & 2002 & 2003 & 2004 & 2005 & 2006 & 2007 & 2008 & 2009 & 2010 & 2011 & 2012 & $\begin{array}{c}\text { Annual } \\
\text { growth } \\
\text { (percentages) }\end{array}$ \\
\hline Total & 60 & 72 & 95 & 121 & 125 & 119 & 111 & 123 & 113 & 106 & 99 & 3.1 \\
\hline North America & 59 & 61 & 86 & 103 & 110 & 101 & 98 & 102 & 86 & 82 & 83 & 1.8 \\
\hline Europe & 29 & 42 & 53 & 69 & 64 & 74 & 65 & 68 & 69 & 67 & 54 & 3.9 \\
\hline Latin America & 7 & 8 & 9 & 7 & 14 & 18 & 17 & 26 & 20 & 22 & 28 & 16.5 \\
\hline MERCOSUR & 3 & 9 & 13 & 13 & 6 & 13 & 13 & 20 & 23 & 26 & 26 & 18.3 \\
\hline Asia & 1 & 3 & 9 & 16 & 13 & 21 & 27 & 32 & 27 & 30 & 27 & 24.9 \\
\hline Africa & & & & 5 & 6 & 3 & 2 & 5 & 4 & 4 & 3 & -4.6 \\
\hline Middle East & & & & 2 & 1 & 2 & 1 & 5 & 3 & 6 & 8 & 41.2 \\
\hline
\end{tabular}

Source: prepared by the authors on the basis of data from the Office of the National Superintendent of Customs and Tax Administration (SUNAT) of Peru.

TABLE 10

Peru: normalized Herfindahl-Hirschman Index for exports of fresh asparagus, 2002-2012

(Percentages)

\begin{tabular}{llllllllllllll}
\hline Market & 2002 & 2003 & 2004 & 2005 & 2006 & 2007 & 2008 & 2009 & 2010 & 2011 & 2012 & $\begin{array}{l}\text { Annual } \\
\text { growth }\end{array}$ \\
\hline
\end{tabular}

Normalized HHI

\begin{tabular}{|c|c|c|c|c|c|c|c|c|c|c|c|c|}
\hline Average & 13.8 & 12.5 & 12.4 & 13.3 & 13.2 & 12.1 & 10.5 & 11.2 & 10.6 & 11.3 & 11.0 & -2.1 \\
\hline North America & 14.9 & 12.2 & 9.5 & 8.4 & 8.1 & 7.8 & 7.6 & 8.8 & 8.9 & 9.7 & 8.1 & -3.8 \\
\hline Europa & 16.7 & 21.9 & 20.6 & 24.0 & 21.8 & 21.2 & 15.6 & 15.7 & 15.3 & 15.4 & 16.3 & -2.9 \\
\hline Latin America & 27.9 & 21.9 & 20.6 & 24.0 & 21.8 & 21.2 & 15.6 & 15.7 & 15.3 & 15.4 & 16.3 & -5.0 \\
\hline MERCOSUR & 8.5 & 22.1 & 13.5 & 24.5 & 31.9 & 41.9 & 11.5 & 16.1 & 13.8 & 20.4 & 17.8 & 0.1 \\
\hline Asia & 0.0 & 27.9 & 62.3 & 57.6 & 41.5 & 49.9 & 30.2 & 21.2 & 19.2 & 21.7 & 22.6 & -3.1 \\
\hline Africa & & & & 46.6 & 56.3 & 41.2 & 26.5 & 19.5 & 25.7 & 45.7 & 34.1 & -5.4 \\
\hline Middle East & & & & 1.1 & 0.0 & 29.3 & 0.0 & 34.3 & 5.5 & 27.0 & 20.7 & 22.1 \\
\hline
\end{tabular}

Source: prepared by the authors on the basis of data from the Office of the National Superintendent of Customs and Tax Administration (SUNAT) of Peru.

be published by the Association of Chilean Exporters (ASOEX) as "Expediente 11". In particular, economic concentration is tending to decline most markedly for table grapes, apples, stone fruits, blueberries, avocados and citric fruits. For pears and kiwi, concentration is low but stable or rising slightly.

\section{Company policy}

(a) The Foreign Trade Policy Index (FTPI)

The purpose of this methodology is to analyse companies' sales policy, and accordingly the index takes a firm's "market share in a trade country or region" as the numerator and the firm's "share of sales" from the country for that product as the denominator:

$$
\mathrm{FTPI}=\left(F S_{k e j} / F S_{k e}\right) /\left(X_{k e} / X_{k i}\right)
$$

where:

$\mathrm{FS}_{k e j}$ foreign sales of product $k$ by firm e in country $\mathrm{j}$ $\mathrm{FS}_{k e}$ foreign sales of product $k$ by firm $e$

$\mathrm{X}_{k e}$ exports of $k$ by firm $e$

$\mathrm{X}_{k i} \quad$ exports of $k$ from country $i$ 
If a particular firm's share of a market is higher than its mean share of the country's exports of the product analysed, this will indicate that the firm specializes in that region. The opposite situation would indicate that its sales in that region were marginal for the time being. The trend will show whether or not the firm is showing an increasing interest in selling in a particular trade country or region.

This tool was developed to gauge how adaptable exporters were to manage changes in international trade under the complexity paradigm (Spilzinger, 2004). It is related to "complex adaptive system" theory (Serlin, 2010), which is based on dynamic systems theory (in mathematics) and complex systems theory (in management). It is this approach that indicates the effectiveness of the methodology (giving a renewed role to trade intelligence as a means of developing creativity in a complex world) via the adaptability of foreign sales management. It is efficacious because it fulfils its purpose (sales policy analysis) and effective when detailed company-level information is available.

Statistical analysis of dissimilarity between firms is carried out on the basis of three items of information for each: its ranking in the Foreign Trade Policy Index (FTPI), the trend of annual changes in the FTPI and annual dollar turnover in each trade region, namely Europe, Asia, Africa, Latin America, the Middle East, MERCOSUR and North America. The combination of these three elements for each exporting firm is what underpins the analysis of dissimilarity between them.

Dissimilarity is measured by Gower's coefficient (Gower, 1967 and 1971), which takes the number of variables with data for pairwise comparisons. A multivariate hierarchical clustering analysis is carried out on the matrix obtained, taking average distances as the linkage criterion.

$$
S_{i j}=\frac{1}{p} \sum_{k=1}^{p} S_{i j k}
$$

In the most straightforward situation, when individuals $I$ and $j$ are compared to character $k$, if this is a binary or qualitative variable, then the value one (1) is assigned to $S \mathrm{i}_{j k}$ if $X_{i k}$ and $X_{j k}$ are the same, and zero (0) if they are different. If the variable is quantitative, the similarity between individuals will be given by:

$$
\begin{gathered}
S_{i j k}=1-\frac{\left\|x_{l k}-x_{j k}\right\|}{r_{k h}}: S_{i j} \\
=\sum_{k=1}^{p_{1}}\left(1-\frac{\left\|x_{i k}-x_{j k}\right\|}{r_{k}}+a+d+\propto\right) / p_{1}+p_{2}+p_{3}
\end{gathered}
$$

where:

$p_{1} \quad$ number of quantitative variables

$r_{k} \quad$ range of the $k$-th continuous variable

$p_{2} \quad$ number of binary variables

$a$ number of 1-1 matches for the binary variables

$d$ number of 0-0 matches for the binary variables $\left(p_{2}-d\right)$

$p_{3} \quad$ number of qualitative variables

$\alpha \quad$ number of matches for the qualitative variables

\section{(b) Sales planning}

The statistical analysis using Gower's coefficient to prepare a dissimilarity matrix, supplemented by a hierarchical clustering analysis of leading firms (see figure 3), confirms the low level of trade policy similarity when these firms are compared. This can then be seen by comparing turnover by market, FTPI rankings and annual rates of change (2004-2012) across the main exporters.

As an example, asymmetries or differences can clearly be seen in the competitiveness maps of the exporters in the Beta Agroindustrial Complex (see figure 4) and Camposol (see figure 5). Besides these two cases, the leading firms generally differ from one another in their sales turnover in each market and the annual rate of change in their trade positioning or share. This evidence bears out the new paradigm of segmented markets as a process of trade adaptation in the face of change, since each firm is seeing the opportunities and threats in each market differently.

\section{Market positioning}

\section{(a) Import competitiveness matrix (TradeCAN)}

The focus of analysis this time is the import market, with the goal of detecting changes on the side of international suppliers but also of revealing the implications and scope of the new dynamic competitiveness paradigm.

In the present case, the objective is to understand the dynamic of Peru and its competitors in a major importing country (figure 1: United States, Netherlands, Spain and the United Kingdom) and grasp strategic changes in trade prices and volumes, with the construction of a TradecAn competitiveness matrix as developed by the Economic Commission for Latin America and the Caribbean (ECLAC) and already used in other studies (Dussel, 2001; Clemente, 2001; Toro and Ruiz, 2005; Matesanz and Sánchez Díez, 2005; Romo Murillo, 2007; Ponce, Contreras and Vásquez, 2007; Sánchez Díez and Villalobos Álvarez, 2010). To measure a country's competitiveness for a product, two variables are related, 
FIGURE 3

Peru: dissimilarity of trade policies at the leading firms studied ${ }^{a}$

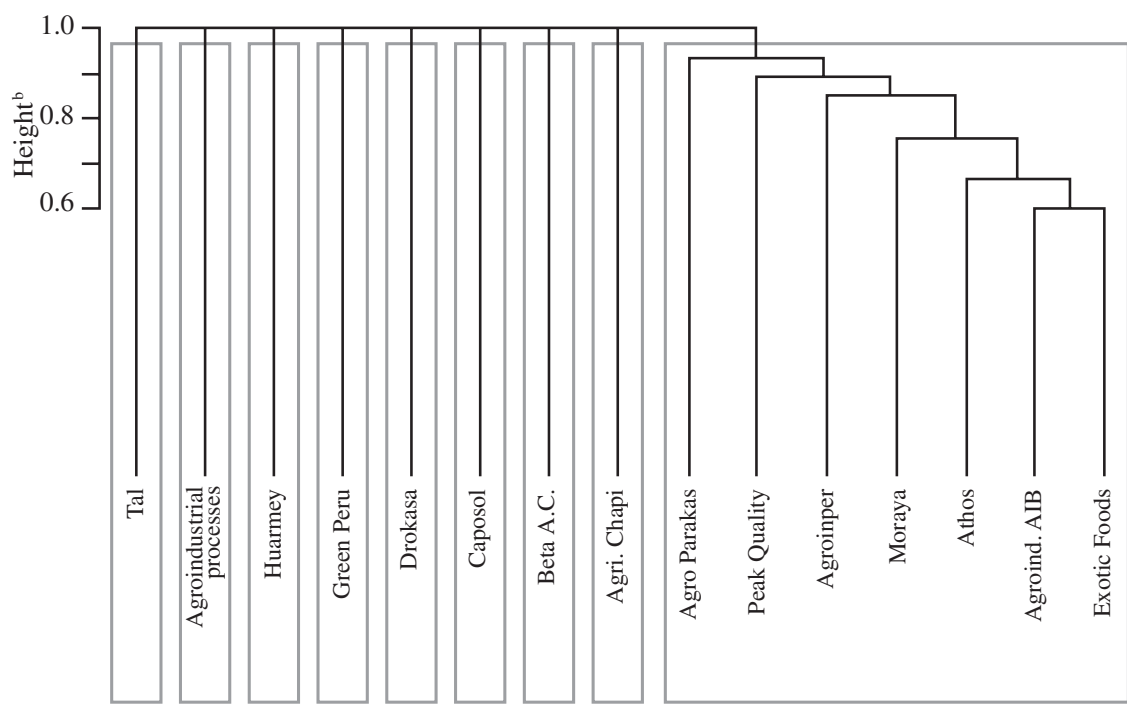

Nine clusters

UPGMA method

hclust (*, "average"

Source: prepared by the authors on the basis of data from the Office of the National Superintendent of Customs and Tax Administration (SUNAT) of Peru.

a The chart was constructed using the "hclust" function of the R statistics program. The vertical axis shows the height at which the clusters are grouped. The horizontal axis shows the number of clusters using the UPGMA or "average" method.

b The "height" variable represents the distance calculated using the UPGMA method at which the different elements and then the different groups formed come together. This is expressed by the values $0.6,0.8$ and 1.0 , which are relative references, with 1.0 being the maximum cluster distance and 0.6 being $60 \%$ of the maximum distance. These values give a visual idea of the scale of the distances at which clustering takes place.

FIGURE 4

Beta Agroindustrial Complex: trade policy trend, 2004-2012

(Percentages)

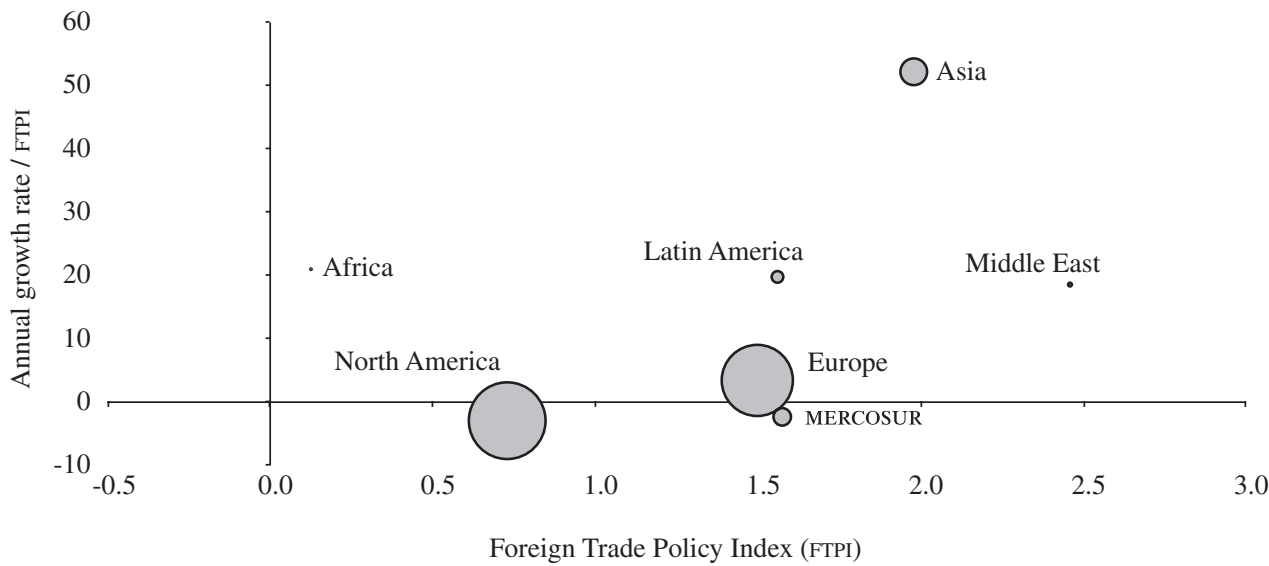

Source: prepared by the authors on the basis of data from the Office of the National Superintendent of Customs and Tax Administration (SUNAT) of Peru.

Note: circle size indicates the value of exports in 2012. 
FIGURE 5

Camposol: trade policy trend, 2004-2012

(Percentages)

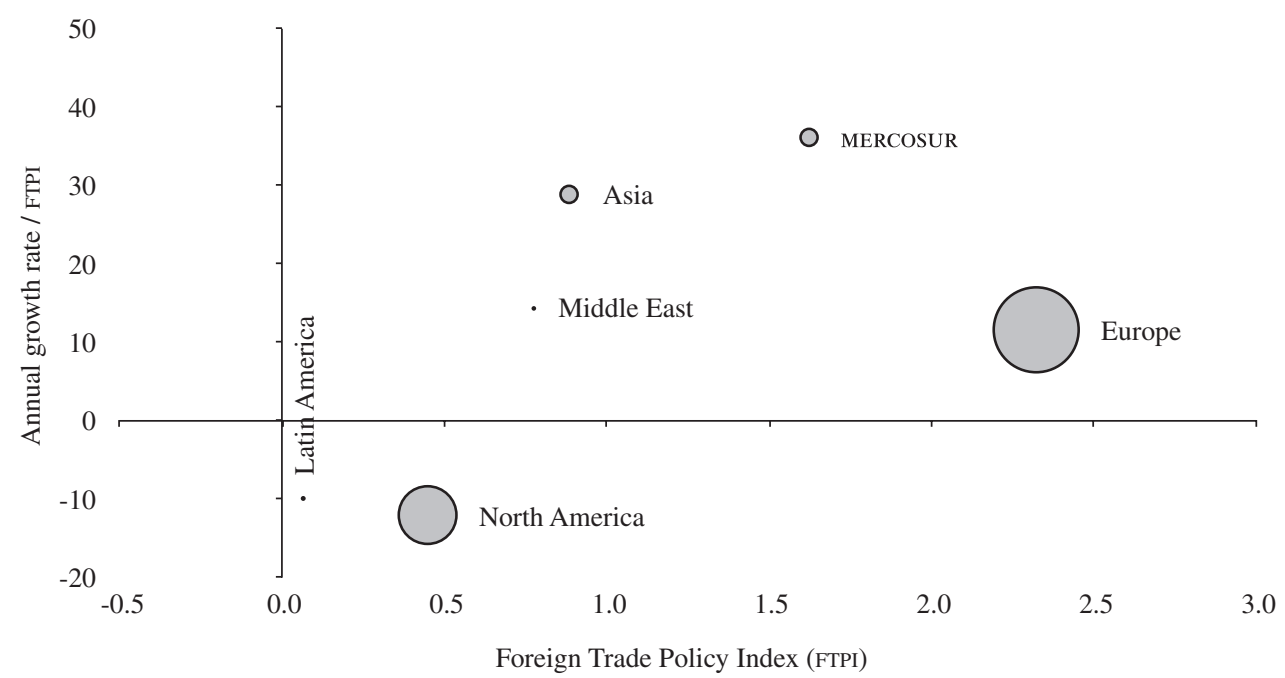

Source: prepared by the authors on the basis of data from the Office of the National Superintendent of Customs and Tax Administration (SUNAT) of Peru.

Note: circle size indicates the value of exports in 2012.

the exogenous factor and the endogenous one. The first of these (the exogenous factor) concerns changes in the international market, while the second (the endogenous factor) relates to each country's ability to respond to alterations in the first variable, either by increasing or reducing exports, depending on the product dynamic. The matrix on the horizontal $(\mathrm{X})$ axis measures the behaviour of the first factor, while the second factor is measured on the vertical (Y) axis. The ratio between these two variables allows four different situations to be distinguished: rising stars, declining stars, retreats, and missed opportunities.

\section{(b) The United States}

This is a market dependent on imports because of declining local production and rising consumption. Mexican asparagus, as a "rising star", dominates the supply year-round (see figures 6 and 7). Mexico's trade is $58 \%$ of the international supply by volume for the year in the first semester and up to $42 \%$ during the second. Mexico sells $20 \%$ of its asparagus in the second semester, while asparagus represents $80 \%$ of Peruvian shipments in that period.

In Peru, there has to be pressure for higher asparagus export prices on cost, insurance and freight (CIF) terms because dollar costs have been rising as the local currency has strengthened (see figure 2), by contrast with Mexico (see figures 8 and 9). While the price outlook for Mexican asparagus is different, Peru has a growing need to diversify its markets.

Prices are usually higher in the second half than in the first (see table 11), particularly export logistics costs, with commercialization and brokerage costs holding steady. This explains why the retail or consumer price in the United States does not increase in proportion to the rise in export or prices FOB, something that derives from the problem of Peru's exchange rate and its repercussions for dollar costs.

\section{(c) The Netherlands}

In 2012, 55\% of the year's imports were made in the first half and $45 \%$ in the second. Purchase volumes trended downward in the first period, falling by $11.2 \%$ a year from 2008 to 2012. Local asparagus production takes place between April and July, and the trend is positive, as output rose from 14,000 to 17,000 tons in the period analysed, which accounts for the slowdown of imports in the first half.

The market share of Greek asparagus, once 12\%, is now down to $1 \%$, while by 2012 the German share was down from $57 \%$ to $3 \%$, with sales being reoriented towards the Swiss market for the early and central part 
FIGURE 6

United States: TradecAN matrix for first-half imports, 2008-2012

(Percentages)

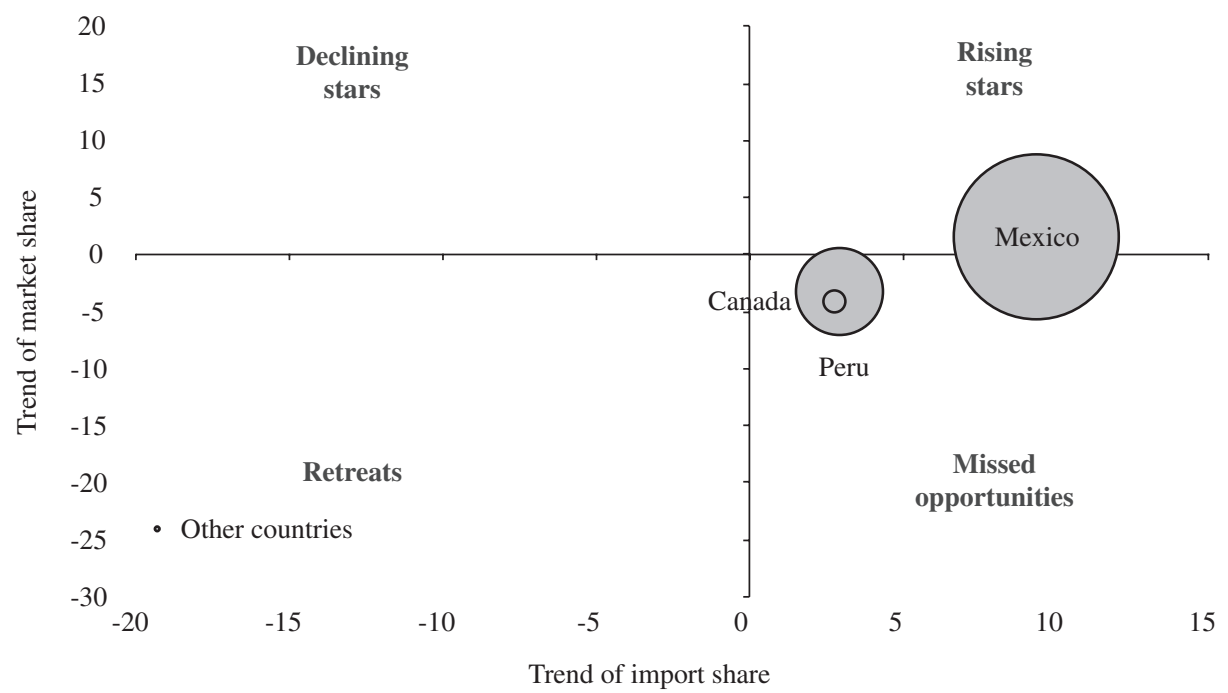

Source: prepared by the authors on the basis of data from the International Trade Centre (ITC) and the United Nations Commodity Trade Statistics Database (COMTRADE).

FIGURE 7

United States: TradecAN matrix for second-half imports, 2008-2012

(Percentages)

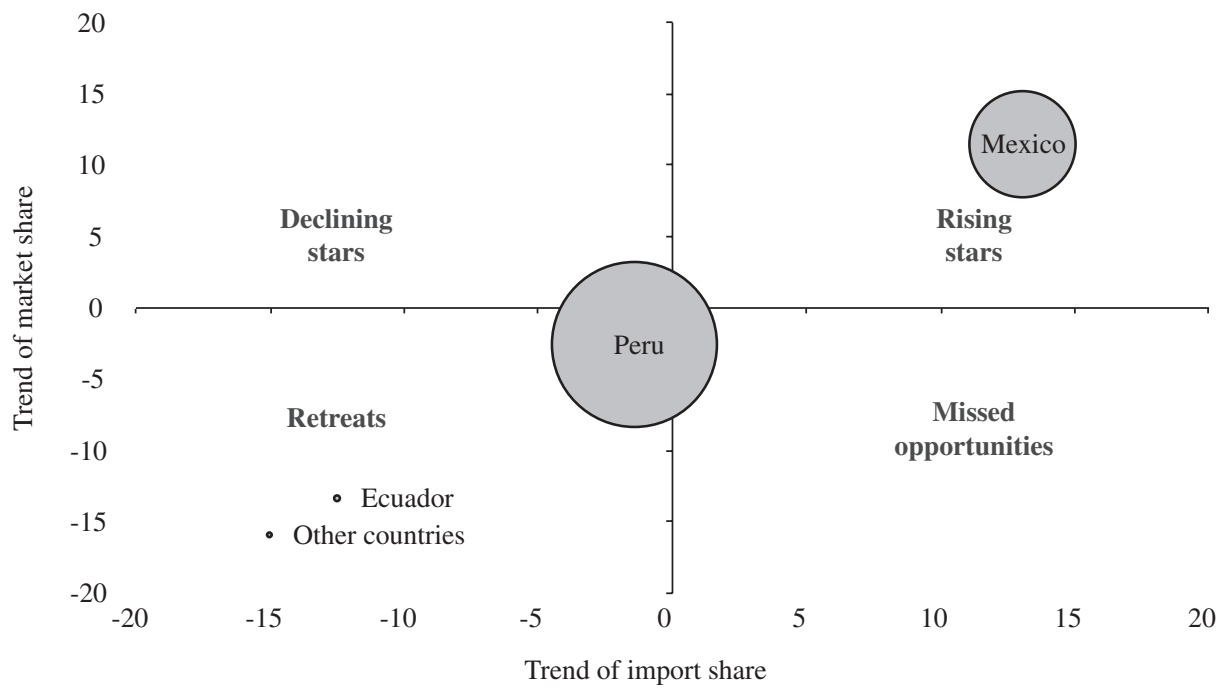

Source: prepared by the authors on the basis of data from the International Trade Centre (ITC) and the United Nations Commodity Trade Statistics Database (COMTRADE). 
FIGURE 8

\section{United States: trade analysis for first-half imports, 2008-2012}

(Percentages)

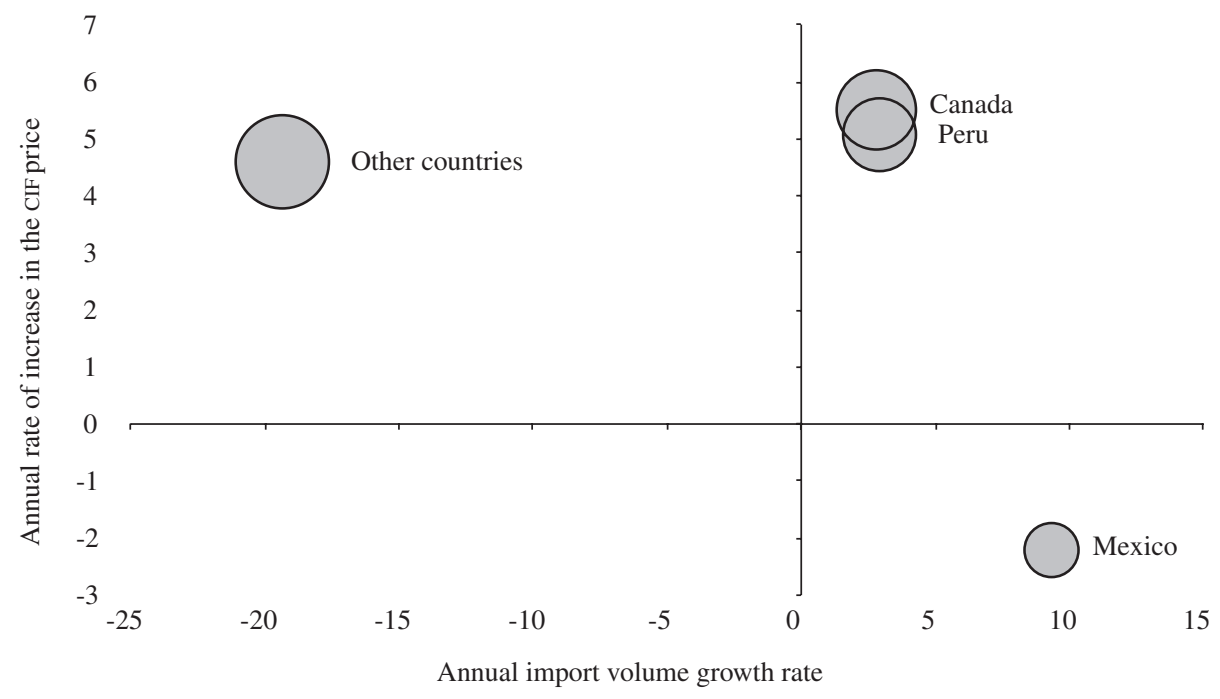

Source: prepared by the authors on the basis of data from the International Trade Centre (ITC) and the United Nations Commodity Trade Statistics Database (COMTrADE).

CIF: cost, insurance and freight.

FIGURE 9

United States: trade analysis for second-half imports, 2008-2012

(Percentages)

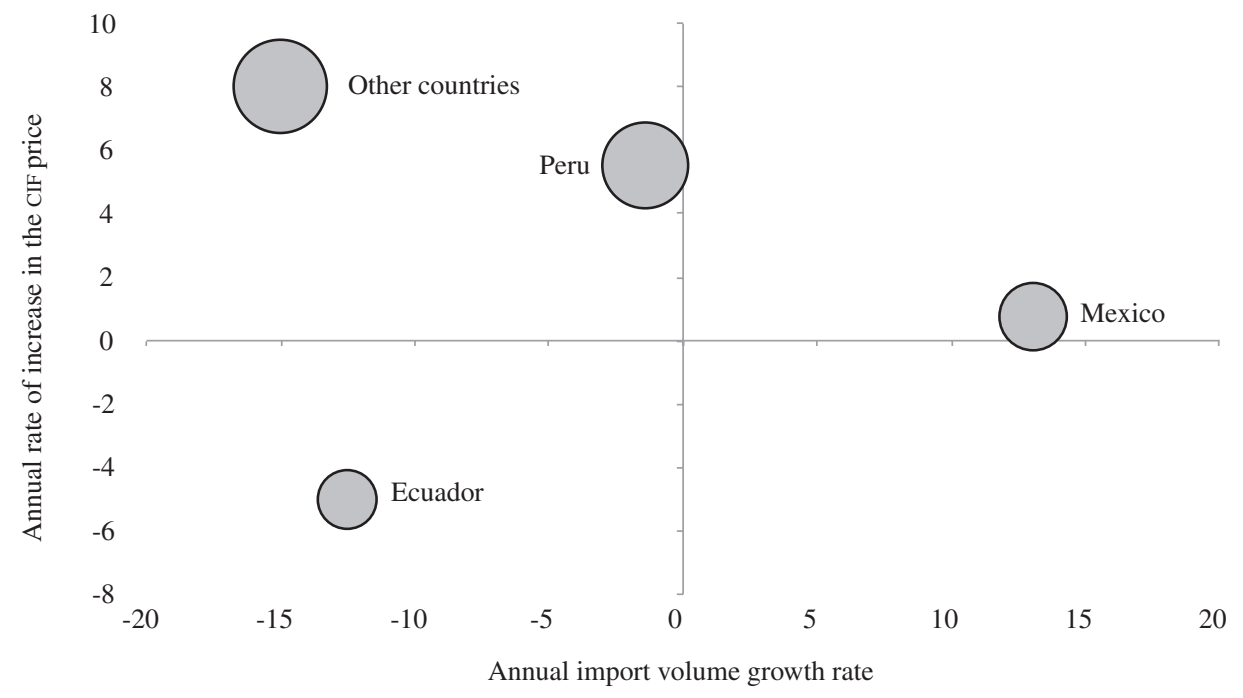

Source: prepared by the authors on the basis of data from the International Trade Centre (ITC) and the United Nations Commodity Trade Statistics Database (COMTRADE).

CIF: cost, insurance and freight. 
United States: trade prices for Peruvian asparagus. 2008-2012 (Dollars per kilogram)

\begin{tabular}{|c|c|c|c|c|c|c|}
\hline July to December & 2008 & 2009 & 2010 & 2011 & 2012 & $\begin{array}{c}\text { Annual change } \\
\text { (percentages) }\end{array}$ \\
\hline Price FOB in Peru & 1.79 & 1.80 & 2.48 & 2.18 & 2.67 & 6.5 \\
\hline CIF price in United States & 2.62 & 2.65 & 3.42 & 3.20 & 3.69 & 5.6 \\
\hline - Commercialization & 3.46 & 2.80 & 2.36 & 3.09 & 3.01 & -1.2 \\
\hline Retail price in United States & 6.09 & 5.46 & 5.77 & 6.28 & 6.70 & 2.1 \\
\hline January to June & 2008 & 2009 & 2010 & 2011 & 2012 & $\begin{array}{c}\text { Annual change } \\
\text { (percentages) }\end{array}$ \\
\hline Price FOB in Peru & 1.94 & 1.94 & 1.93 & 2.07 & 2.74 & 5.2 \\
\hline - Logistics & 0.71 & 0.72 & 0.83 & 0.90 & 0.92 & 4.7 \\
\hline CIF price in United States & 2.65 & 2.66 & 2.76 & 2.97 & 3.66 & 5.1 \\
\hline - Commercialization & 2.88 & 2.59 & 2.63 & 3.17 & 2.66 & 0.3 \\
\hline Retail price in United States & 5.54 & 5.25 & 5.38 & 6.14 & 6.32 & 2.7 \\
\hline
\end{tabular}

Source: prepared by the authors on the basis of data from the Office of the National Superintendent of Customs and Tax Administration (SUNAT) of Peru. the United States Department of Agriculture and the United Nations Commodity Trade Statistics Database (COMTRADE).

CIF: cost. insurance and freight.

FOB: free on board.

of the harvesting period. This gap in the first half has been filled by asparagus from Mexico and Peru, which explains their position as "rising stars", while Germany and Greece are "retreats" (see figure 10).

For the second half, the average annual rate of supply growth in the period from 2008 to 2012 was $5.7 \%$, a contrast to the early months of the year. Peru dominates the second part of the year with a $93 \%$ market share. Otherwise, there have been small changes in suppliers, such as the growth of Germany and Spain, which have been positioning themselves as "rising stars" for the later part of their harvest, displacing sales from Thailand and other countries, particularly the United Kingdom and Belgium, which are now "retreats" (see figure 11).

In the first half, sales in Germany and Greece are associated with a more selective supply and higher prices (see figure 12), while the rising sales of Mexico and Peru are not associated with any substantial increase in prices, which rose by $1.6 \%$ and $1 \%$ a year, respectively.

In the second half, however, Peru, Germany and Spain can all show higher CIF prices (see figure 13).

The increase in the CIF price for Peruvian asparagus imported into the Netherlands is mainly accounted for by rising international logistics costs in both the first and second halves, owing to rising prices FOB origin (see table 12).

\section{(d) Spain}

Asparagus produced in Spain is harvested in the first half, with volume increasing from 44,000 to 58,000 tons between 2008 and 2011. Imports into this market by volume are divided equally between the first and second halves, although consumption is higher from January to June because of local production. Purchases from Morocco, Mexico and the Netherlands take place in the early part of the year, while Peru ships $41 \%$ of its sales from January to June. Mexico and the Netherlands are the "rising stars" in this period, while Morocco is a "retreat" (see figure 14).

All consumption in the second half is about imported asparagus, and Peru sends 59\% of its annual shipments in this period, with a market share of $97 \%$ by value, while Ecuador's small sales make it a "rising star", filling the gap left by the "retreat" of Morocco and France (see figure 15).

The trading strategy is a policy of price adjustment in the first half (see figure 16), although this is more the case of asparagus sold from the Netherlands than for Mexican asparagus.

The improved position of Peru is explained by the increase in prices and thence in turnover, with only a small increase in volume. This explains why the CIF price rose at an average annual rate of $2.6 \%$ (see figure 17), driven by the rise in domestic costs as the real exchange rate of the Peruvian currency against the United States dollar strengthened. The rising price of asparagus imported from Peru is very likely to be acting as a constraint on second-half sales growth, explaining why sales volumes held steady between 2008 and 2012 .

In summary, the CIF price of Peruvian asparagus in Spain in the first half has tended to rise owing to the combination of a higher price $\mathrm{FOB}$ and rising international 
FIGURE 10

Netherlands: TradeCAN matrix for first-half imports, 2008-2012

(Percentages)

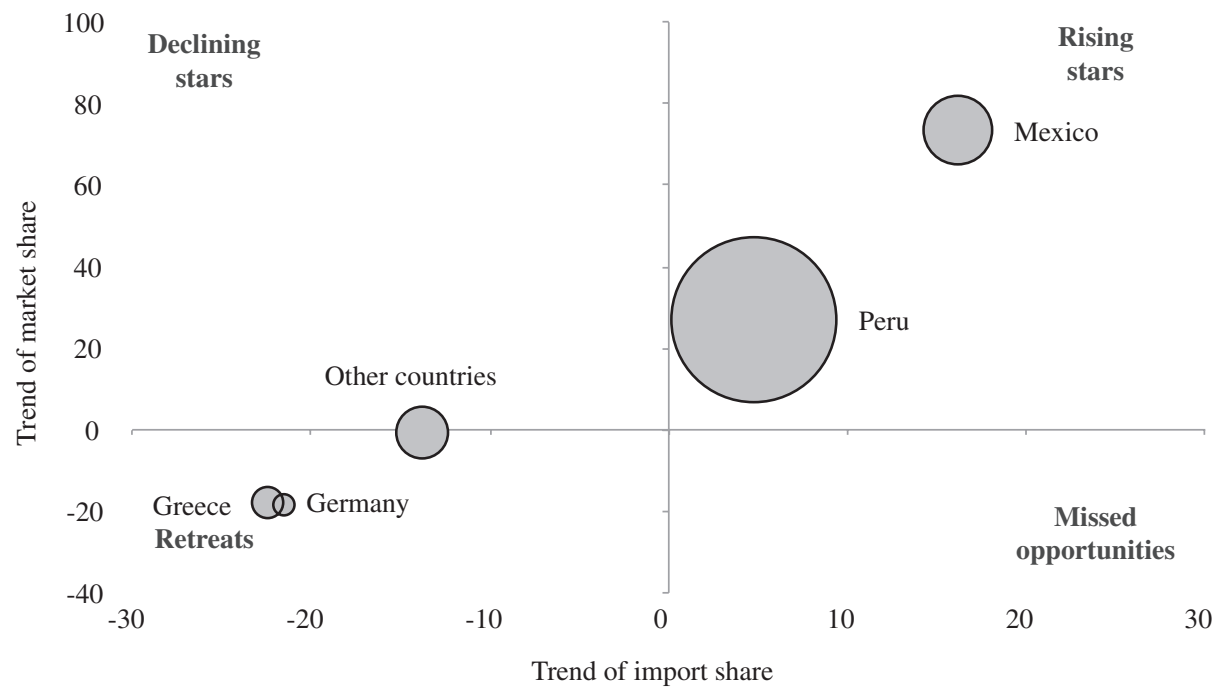

Source: prepared by the authors on the basis of data from the International Trade Centre (ITC) and the United Nations Commodity Trade Statistics Database (COMTRADE).

FIGURE 11

Netherlands: TradeCAN matrix for second-half imports, 2008-2012

(Percentages)

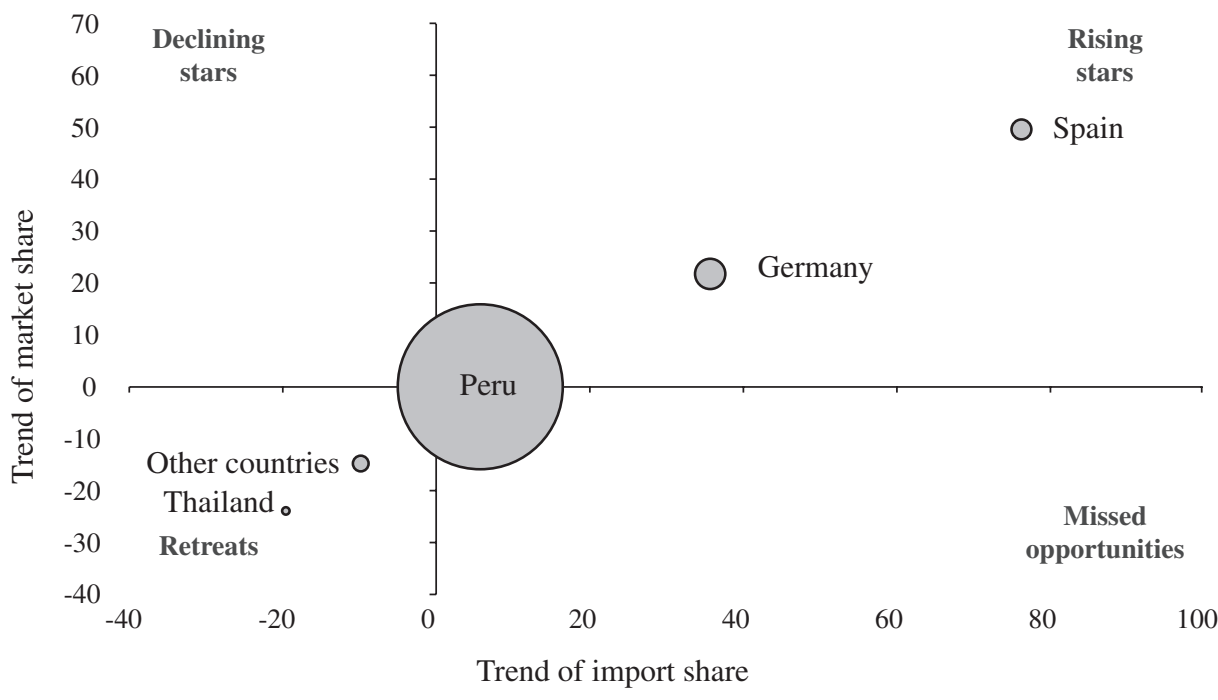

Source: prepared by the authors on the basis of data from the International Trade Centre (ITC) and the United Nations Commodity Trade Statistics Database (COMTRADE). 
FIGURE 12

Netherlands: trade analysis for first-half imports, 2008-2012

(Percentages)

20

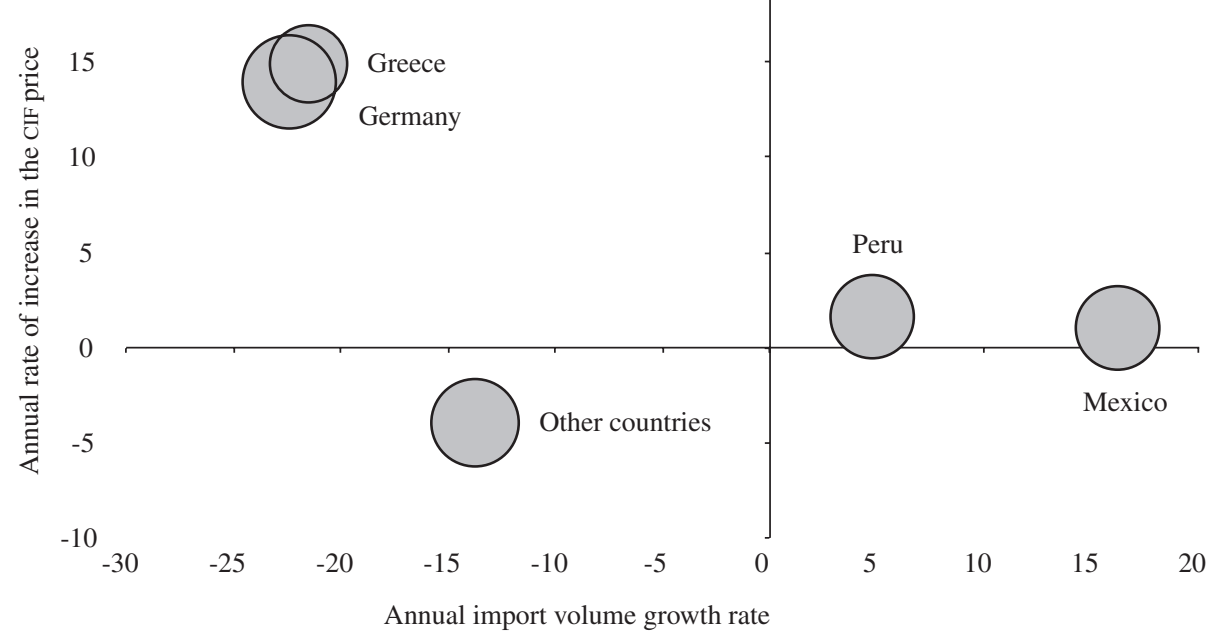

Source: prepared by the authors on the basis of data from the International Trade Centre (ITC) and the United Nations Commodity Trade Statistics Database (COMTRADE)

CIF: cost, insurance and freight.

FIGURE 13

Netherlands: trade analysis for second-half imports, 2008-2012

(Percentages)

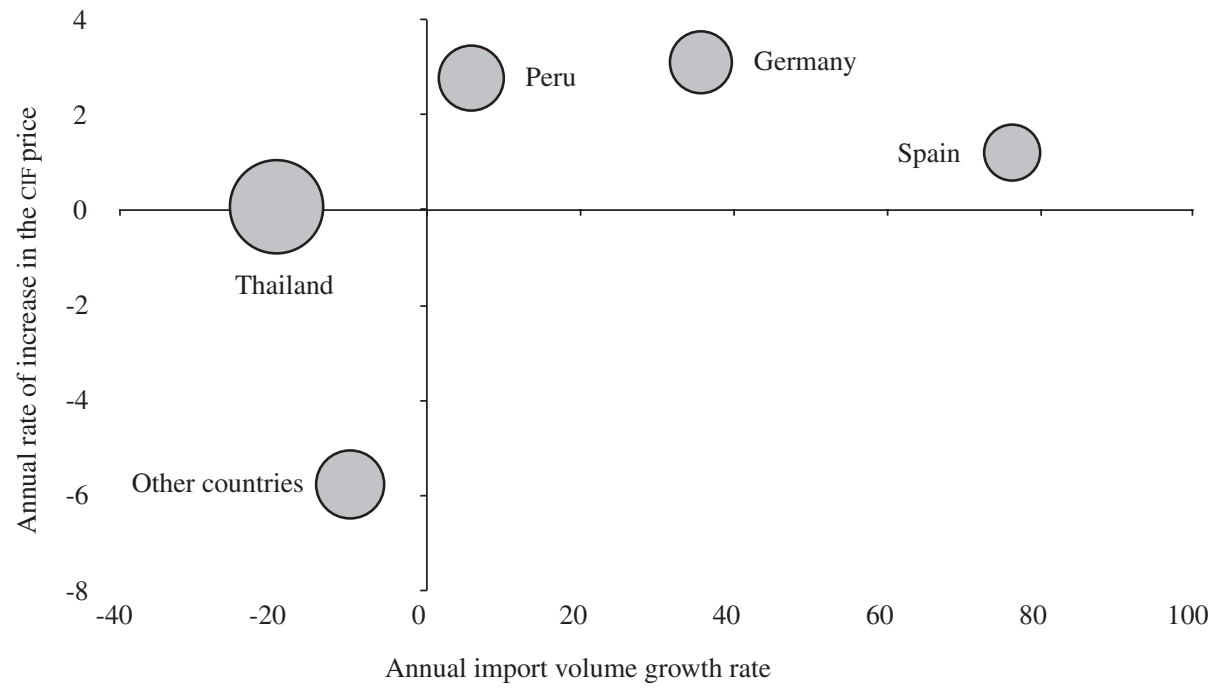

Source: prepared by the authors on the basis of data from the International Trade Centre (ITC) and the United Nations Commodity Trade Statistics Database (COMTRADE)

CIF: cost, insurance and freight. 
TABLE 12

Netherlands: trade prices for Peruvian asparagus, 2008-2012

(Dollars per kilogram)

\begin{tabular}{|c|c|c|c|c|c|c|}
\hline July to December & 2008 & 2009 & 2010 & 2011 & 2012 & $\begin{array}{c}\text { Annual change } \\
\text { (percentages) }\end{array}$ \\
\hline Price FOB in Peru & 3.05 & 2.99 & 3.44 & 3.21 & 3.25 & 1.2 \\
\hline - Logistics & 1.06 & 1.01 & 1.29 & 1.23 & 1.64 & 7.3 \\
\hline CIF price in Netherlands & 4.11 & 4.00 & 4.73 & 4.44 & 4.88 & 2.8 \\
\hline January to June & 2008 & 2009 & 2010 & 2011 & 2012 & $\begin{array}{l}\text { Annual change } \\
\text { (percentages) }\end{array}$ \\
\hline Price FOB in Peru & 3.35 & 3.16 & 3.35 & 3.42 & 3.20 & -0.1 \\
\hline - Logistics & 0.79 & 0.88 & 0.82 & 1.12 & 1.25 & 8.0 \\
\hline CIF price in Netherlands & 4.14 & 4.04 & 4.17 & 4.54 & 4.45 & 1.6 \\
\hline
\end{tabular}

Source: prepared by the authors on the basis of data from the Office of the National Superintendent of Customs and Tax Administration (COMERCIO) of Peru, the United States Department of Agriculture and the United Nations Commodity Trade Statistics Database (COMTRADE).

CIF: cost, insurance and freight.

FOB: free on board.

FIGURE 14

Spain: TradeCAN matrix for first-half imports, 2008-2012

(Percentages)

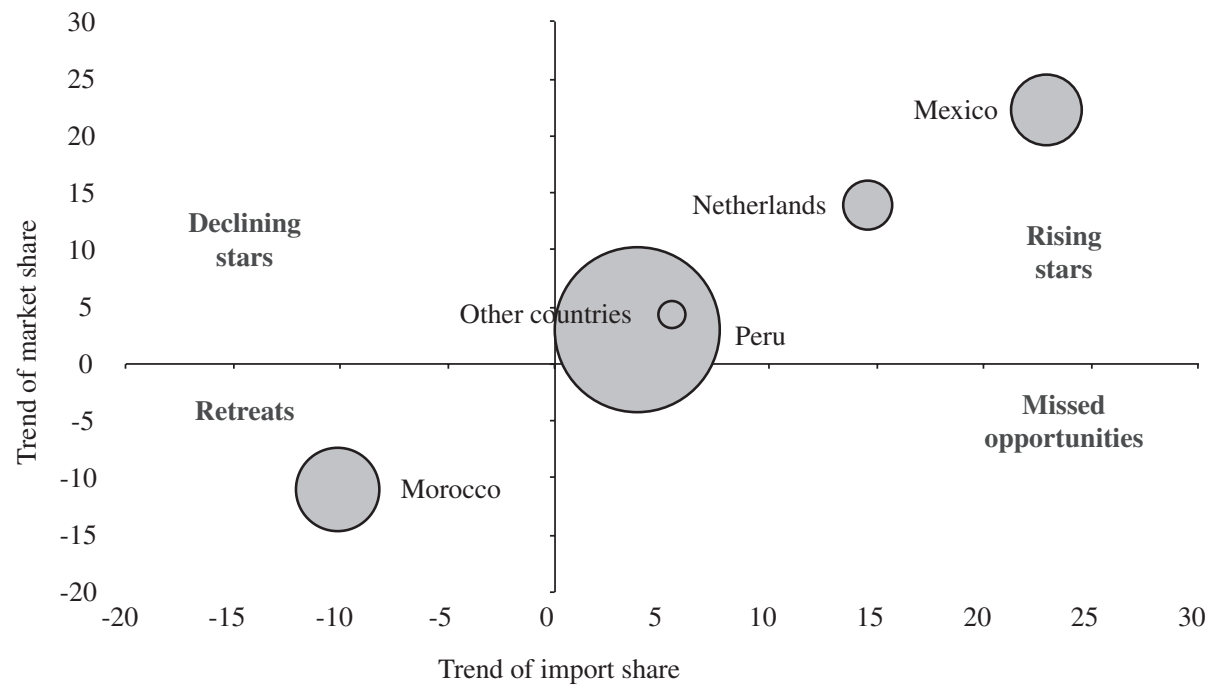

Source: prepared by the authors on the basis of data from the International Trade Centre (ITC) and the United Nations Commodity Trade Statistics Database (COMTRADE). 
FIGURE 15

Spain: TradeCAN matrix for second-half imports, 2008-2012

(Percentages)

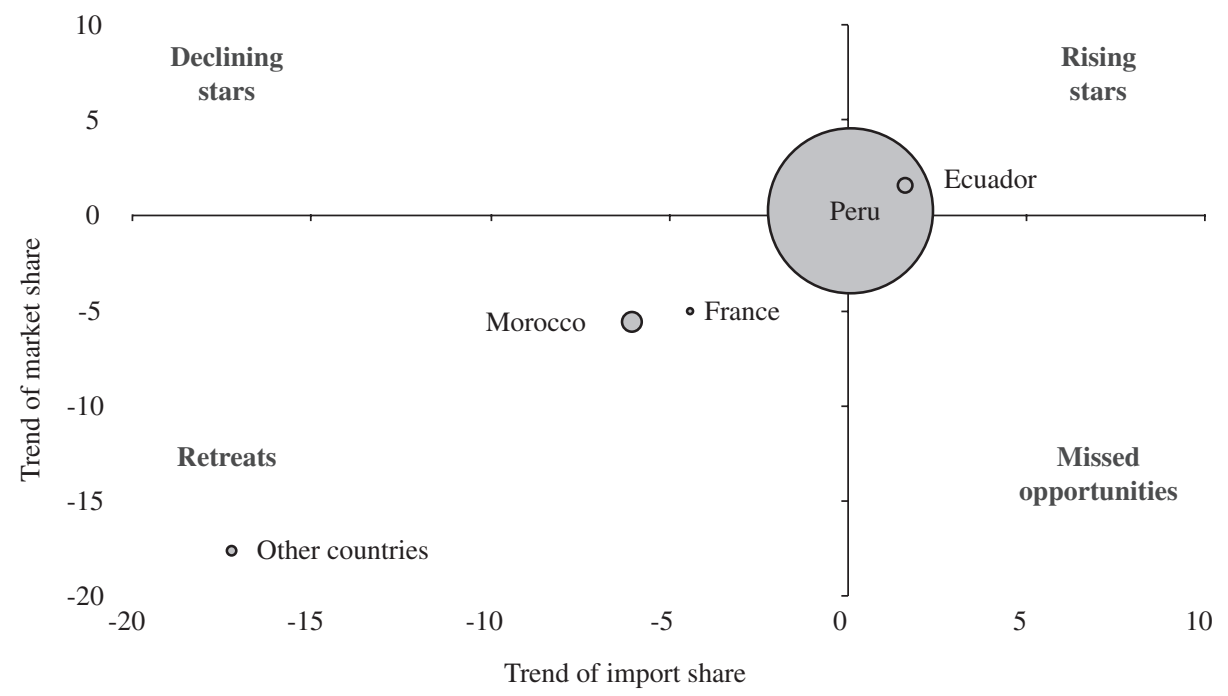

Source: prepared by the authors on the basis of data from the International Trade Centre (ITC) and the United Nations Commodity Trade Statistics Database (COMTRADE).

FIGURE 16

Spain: trade analysis for first-half imports, 2008-2012

(Percentages)

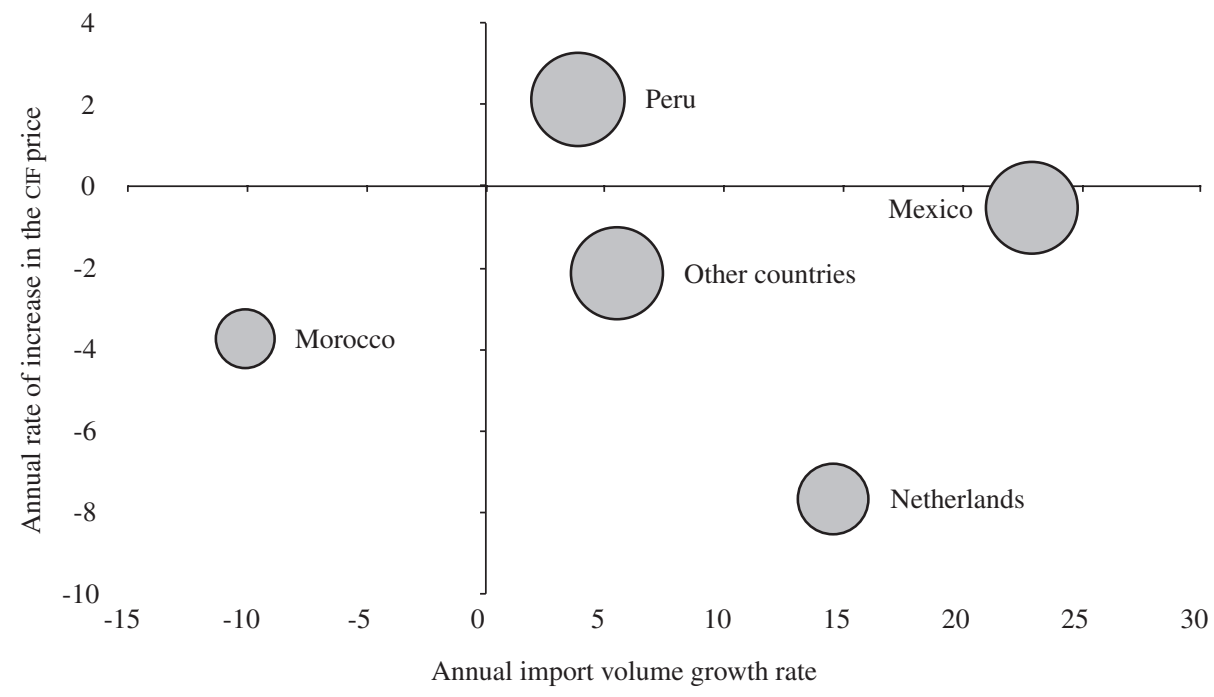

Source: prepared by the authors on the basis of data from the International Trade Centre (ITC) and the United Nations Commodity Trade Statistics Database (COMTRADE).

CIF: cost, insurance and freight. 
FIGURE 17

Spain: trade analysis for second-half imports, 2008-2012

(Percentages)

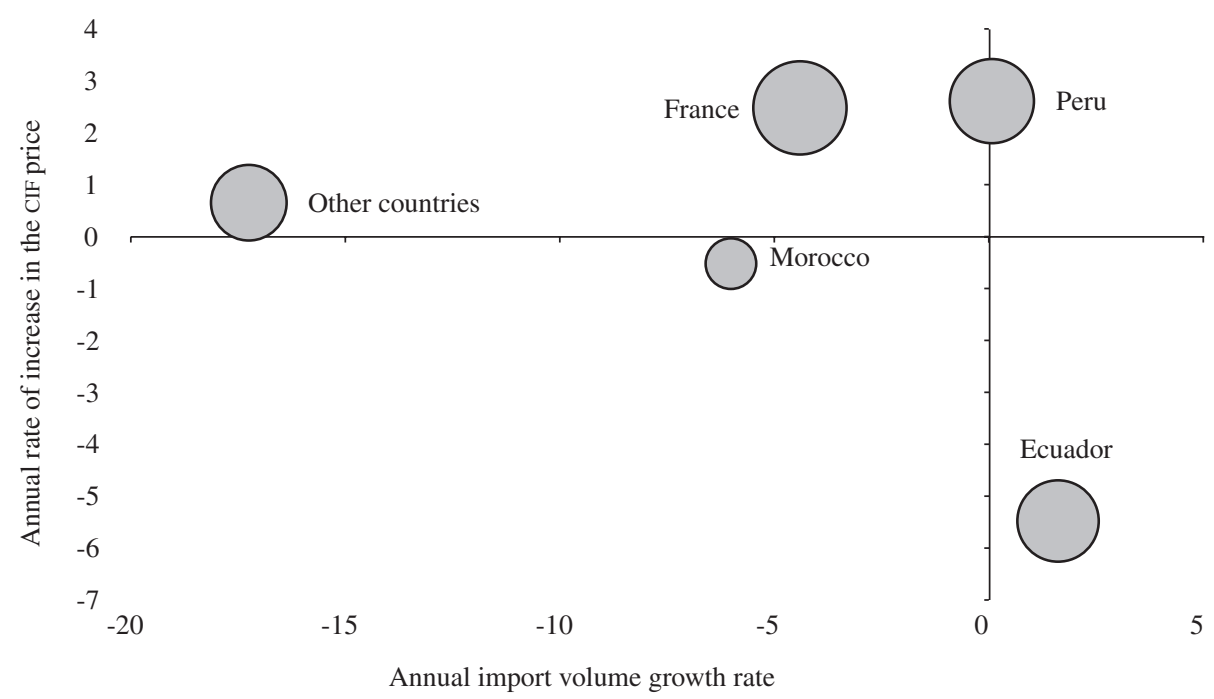

Source: prepared by the authors on the basis of data from the International Trade Centre (ITC) and the United Nations Commodity Trade Statistics Database (COMTrade).

CIF: cost, insurance and freight.

logistics costs. In the second half, however, the change in the CIF price is accounted for by the higher price FOB alone (see table 13).

\section{(e) United Kingdom}

The health benefits of consuming vegetables, particularly asparagus for diabetics, ${ }^{3}$ have strongly supported consumption in the United Kingdom. Some $46 \%$ of annual imports fall in the January to June period (supplemented by the local supply from April to June, with local production increasing from 32,000 to 51,000 tons between 2008 and 2011), with the other $54 \%$ falling between July and December.

While $98 \%$ of Mexico's annual sales in this market is made in the first half, the figure for Peru is $30 \%$, with the other $70 \%$ being made from July to December. Mexico is once again a "rising star", along with Italy, in the first half (see figure 18) because of rising sales, while Spain and Peru are in "retreat".

The second half is dominated by shipments from Peru, while the small supply from the Netherlands (whose origin is unknown) makes it a "rising star" occupying

3 See [online] http://www.dailymail.co.uk/health/article-2236322/ Asparagus--trendy-vegetable-fights-diabetes.html. the gap left by the "retreat" of Kenya and Thailand (see figure 19).

In the first half, Peru's "retreat" is explained by its objective of obtaining better selling prices FOB, while Italy has become a "rising star" with its policy of lower prices (see figure 20).

Spain has been in "retreat" from January to June, with both lower volumes and falling prices. Kenya in the second half is in much the same position as Spain in the first, while Thailand has been obtaining better prices FOB for a smaller volume, even as the "rising star" that is the Netherlands has increased both volume and prices (see figure 21).

Peru's second-half CIF prices have also been improved, and this increase is a factor that may well account for the stability of consumption in the United Kingdom.

By contrast with the United States market, one peculiarity of the United Kingdom is that the increase in the CIF price of Peruvian asparagus imports has been mainly due to the rise in international logistics costs in both the first and second halves, owing to the rise in the FOB origin price (see table 14). In general terms, the strengthening of the pound sterling and euro against the dollar has also helped to absorb some of the increase in dollar-denominated domestic costs in the period analysed. 
TABLE 13

Spain: trade prices for Peruvian asparagus, 2008-2012

(Dollars per kilogram)

\begin{tabular}{lcccccc}
\hline July to December & 2008 & 2009 & 2010 & 2011 & 2012 & $\begin{array}{c}\text { Annual change } \\
\text { (percentages) }\end{array}$ \\
\hline Price FOB in Peru & 1.97 & 2.09 & 2.64 & 2.39 & 2.89 & 5.8 \\
- Logistics & 2.13 & 1.97 & 1.58 & 2.01 & 1.95 & -1.0 \\
CIF price in Spain & 4.10 & 4.06 & 4.23 & 4.40 & 4.84 & 2.6 \\
\hline January to June & 2008 & 2009 & 2010 & 2011 & 2012 & $\begin{array}{c}\text { Annual change } \\
\text { (percentages) }\end{array}$ \\
\hline Price FOB in Peru & 2.10 & 2.12 & 2.14 & 2.27 & 2.63 & 3.4 \\
- Logistics & 1.89 & 1.71 & 3.10 & 3.31 & 3.36 & 12.1 \\
CIF price in Spain & 3.99 & 3.83 & 5.24 & 5.58 & 5.99 & 7.8 \\
\hline
\end{tabular}

Source: prepared by the authors on the basis of data from the Office of the National Superintendent of Customs and Tax Administration (sunat) of Peru, the United States Department of Agriculture and the United Nations Commodity Trade Statistics Database (COMTRAdE).

CIF: cost, insurance and freight.

FOB: free on board.

FIGURE 18

United Kingdom: TradecAN matrix for first-half imports, 2008-2012

(Percentages)

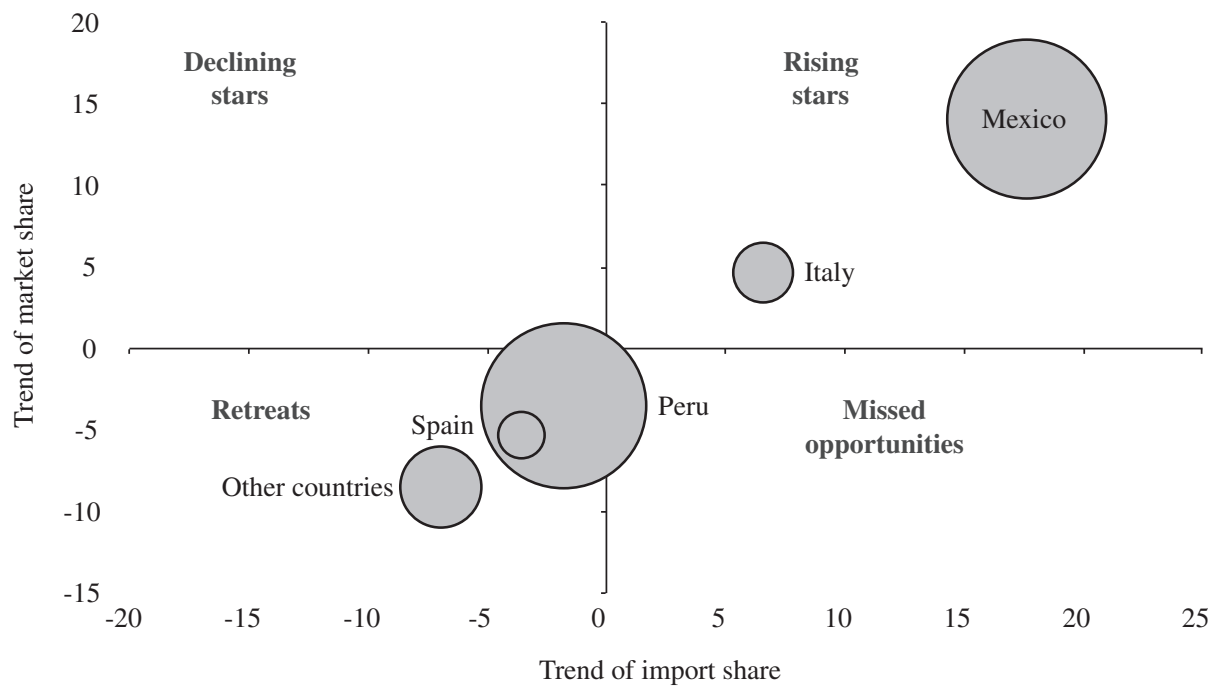

Source: prepared by the authors on the basis of data from the International Trade Centre (ITC) and the United Nations Commodity Trade Statistics Database (COMTRADE). 
FIGURE 19

United Kingdom: TradecAN matrix for second-half imports, 2008-2012

(Percentages)

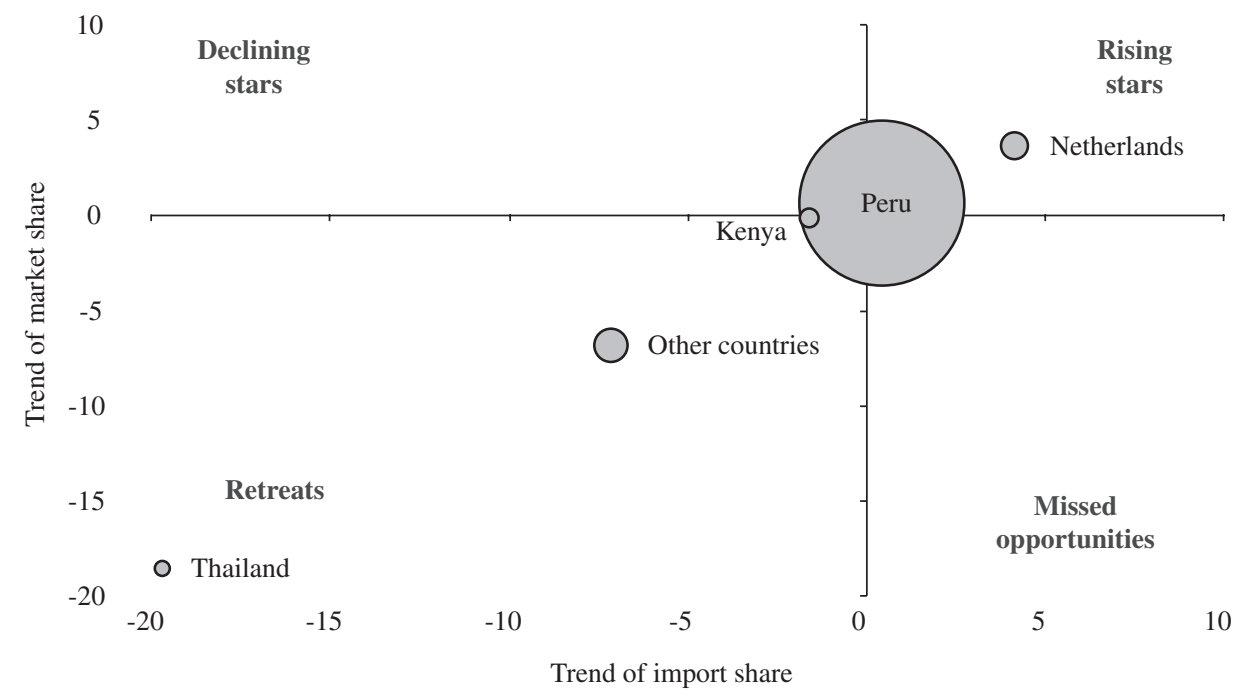

Source: prepared by the authors on the basis of data from the International Trade Centre (ITC) and the United Nations Commodity Trade Statistics Database (COMTRADE).

FIGURE 20

United Kingdom: trade analysis for first-half imports, 2008-2012

(Percentages)

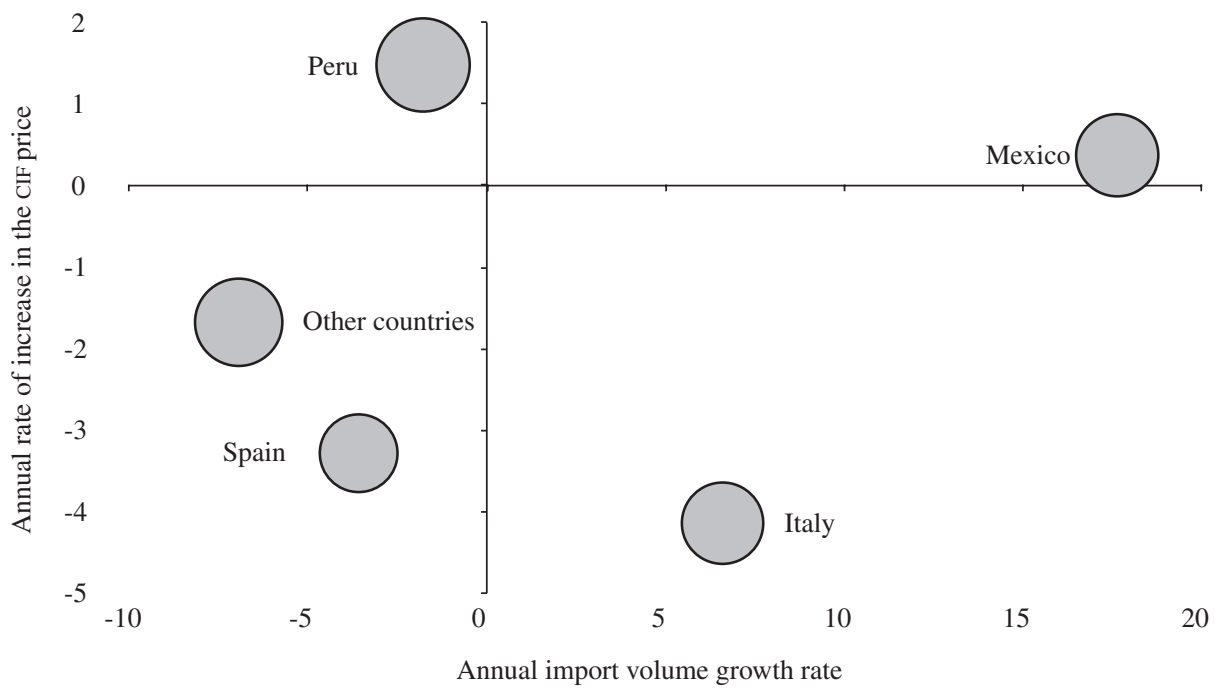

Source: prepared by the authors on the basis of data from the International Trade Centre (ITC) and the United Nations Commodity Trade Statistics Database (COMTRADE).

CIF: cost, insurance and freight. 
FIGURE 21

United Kingdom: trade analysis for second-half imports, 2008-2012

(Percentages)

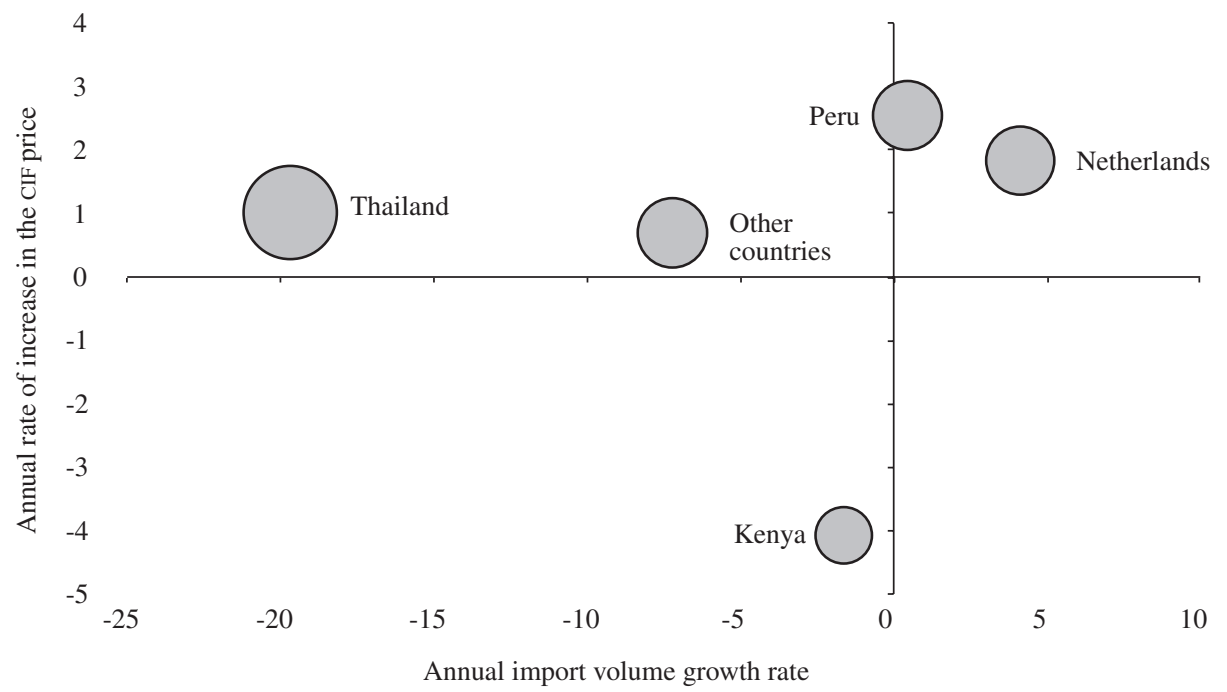

Source: prepared by the authors on the basis of data from the International Trade Centre (ITC) and the United Nations Commodity Trade Statistics Database (COMTRADE).

CIF: cost, insurance and freight.

TABLE 14

United Kingdom: trade prices for Peruvian asparagus, 2008-2012

(Dollars per kilogram)

\begin{tabular}{|c|c|c|c|c|c|c|}
\hline July to December & 2008 & 2009 & 2010 & 2011 & 2012 & $\begin{array}{c}\text { Annual change } \\
\text { (percentages) }\end{array}$ \\
\hline Price FOB in Peru & 2.93 & 3.17 & 3.60 & 3.19 & 3.16 & 0.9 \\
\hline - Logistics & 1.77 & 1.81 & 1.78 & 2.33 & 2.33 & 5.3 \\
\hline CIF price in United Kingdom & 4.70 & 4.98 & 5.38 & 5.52 & 5.49 & 2.5 \\
\hline January to June & 2008 & 2009 & 2010 & 2011 & 2012 & $\begin{array}{l}\text { Annual change } \\
\text { (percentages) }\end{array}$ \\
\hline Price Fob in Peru & 3.58 & 3.19 & 3.09 & 3.40 & 3.11 & -1.3 \\
\hline - Logistics & 1.85 & 1.92 & 2.15 & 2.18 & 2.88 & 7.0 \\
\hline CIF price in United Kingdom & 5.43 & 5.11 & 5.24 & 5.58 & 5.99 & 1.8 \\
\hline
\end{tabular}

Source: prepared by the authors on the basis of data from the Office of the National Superintendent of Customs and Tax Administration (sunat) of Peru, the United States Department of Agriculture and the United Nations Commodity Trade Statistics Database (COMTRADE).

CIF: cost, insurance and freight.

FOB: free on board. 


\section{$\mathrm{V}$}

\section{Conclusions}

Peru has been the unchallenged global leader in asparagus exports in recent years. Its export destinations have been tending to diversify, although sales to the United States still predominate, albeit with a negative trend (see figure 1).

The changes detected in the international trade position of Peruvian asparagus have been very important, providing the basis for a new model known as a complex adaptive system forming part of the fifth technological revolution.

In the first place, there is structural atomization, with a low level of economic concentration (see table 7), particularly in the case of asparagus exports to the United States and Europe, the main trading destinations. The atomization of the export sector is due to the increase in the number of firms (see table 9) and the declining market share of the leading firms, which have been diversifying into other exportable products (table grapes, avocados, pomegranates and blueberries), Camposol is an example. Studying importers also reveals this process of atomization (see table 8) in seaborne cargoes, particularly for sales to the United States market. This can also be seen in the case study dealing with fruit exports from Chile.

Another issue that arises is the dissimilarity of the main exporters' trade policies (see figure 3), which bears out the segmented market paradigm. Structural atomization and dissimilarity in trade policies are elements that support the notion of a complex adaptive system and, with it, a novel process of adaptation to changes in world trade as a characteristic of this new technological revolution.

The competition for Peru comes from Mexican asparagus, a "rising star" (see figure 18) in a number of countries in the first half of the year, examples being the United Kingdom, the Netherlands (see figure 10) and Spain (see figure 14), and all year round in the United States (see figures 6 and 7), one factor in this being the exchange rate of the Mexican peso against the United States dollar (see figure 2).

The bulk of Peru's sales is made in the second half. Sales growth has tailed off in Spain (see figure 17), while the country has some small but growing competitors in the Netherlands (see figure 13: Germany and Spain) and the United Kingdom (see figure 21: Netherlands).
The market dynamic, competition from Mexico, rising logistics costs, exchange-rate movements and the dissimilarity of exporters' trade policies show that in this complex adaptive system, there have been a need to take ever more and better decisions, and that timely, strategic information is a key factor. Even climate change is increasingly influencing the asparagus business in both producing and consuming areas, whether owing to temperatures or to patterns of rainfall or drought. Unquestionably, one constraint on Peru's asparagus model, besides short-term climate factors, is the availability of water, despite public policies on infrastructure for improving irrigation systems.

In the face of these challenges, it is worth mentioning that there are institutions which are making efforts to innovate technologically, but are acting in isolation and not visualizing the need to do so throughout the chain. However, the National Agricultural Innovation Institute (INIA) is the body that heads the National Agricultural Innovation System (SNIA), and public policies should therefore be designed to strengthen it, with private-sector participation being vital to prioritize actions and resource usage. Although there are successful cases of teamwork between the public and private sectors, examples being the Peruvian Asparagus and Vegetables Institute, the Frío Aéreo civil partnership and consultants specializing in logistics and quality control, these all being bodies that work with the new paradigm of flexible, strategic information and knowledge, there is still work to be done on sectoral linkage and on the development of markets such as Germany and Japan. Trade agreements are another important public policy achievement, with sights now set in China and India.

Complementary application of modern methodologies, developed particularly in the fifth technological revolution to study the Peruvian asparagus model and thereby guide strategic decision-making in the sector, is proving to be an efficacious, efficient and effective tool. These methodologies are succeeding in measuring what they are designed to measure and delivering results based on accessible international trade data, although perhaps the firm-level detail indicates that not all countries are taking the trouble to prepare them, making it difficult to carry out a disaggregated analysis exporter by the exporter. These methodologies 
are making an important contribution of up-to-date knowledge that is necessary for understanding the changes and adaptation processes in international trade that are most closely linked to competitiveness, given how dynamic and complex this is. This methodological package consists of the FTCI, which can be used to examine exports of a product (i.e., the FTPI, which serves to put a value on changes in exporters' sales), and the Tradecan competitiveness matrix for researching imports of a product in a particular market, with competition being assessed via changes in sales volumes and prices.

\section{Bibliography}

Alarco, G. and P. del Hierro (2010), "Growth and concentration among the leading business groups in Mexico", CEPAL Review, No. 101 (LC/G.2455-P), Santiago, Chile, August.

Baumann, R. (2009), "El comercio entre los países "BRICs'” (LC/BRS/R.210), Brasilia, ECLAC office in Brasilia [online] http://www.eclac.org/brasil/publicaciones/sinsigla/xml/0/36890/ LCBRSR210RenatoBaumannBRICS.pdf

Benson, B.L. (2012), "2009 Update of the World's Asparagus Production Areas, Spear Utilization and Production Periods" [online] http://www.actahort.org/books/950/950_9.htm.

Caputi Lélis, M.T., A. Moreira Cunha and M. Gomes de Lima (2012), "The performance of Chinese and Brazilian exports to Latin America, 1994-2009”, CEPAL Review, No. 106 (LC/G.2518-P), Santiago, Chile, April.

Clemente, L. (2001), "Venezuela y los indicadores de competitividad", Working Paper, Andean Competitiveness Project [online] http:// www.cid.harvard.edu/archive/andes/documents/workingpapers/ indicators/indicators_venezuela.pdf.

De Pablo Valenciano, J. and M.A. Giacinti Battistuzzi (2013), ¿Pierde posicionamiento España en las exportaciones de limón frente a sus competidores?, Almería, Fundación Cajamar.

(2012a), "The competitiveness of kiwifruit from the Southern hemisphere. 2012 Export forecast", Fresh Point Magazine, year IV, No. 6, Milan, Editorial Ortofrutta Italiana, June.

(2012b), "Competitividad en el comercio internacional vs ventajas comparativas relevadas (VCR). Caso de análisis: Peras", Revista de Economía Agrícola, vol. 59, No. 1, São Paulo, Agricultural Economics Institute [online] ftp://ftp.sp.gov.br/ ftpiea/rea/2012/rea1-4-12.pdf.

(2012c), "Competitividad en el comercio internacional vs ventajas comparativas reveladas (VCR): Ensayo sobre exportaciones de manzanas de América del Sur", Revista Mexicana de Economía Agraria y Recursos Naturales, No. 6, Chapingo, Chapingo Autonomous University.

De Pablo Valenciano, J. and M.A. Giacinti Battistuzzi and J. Uribe (2012), "Revealed comparative advantage and competitiveness in pear", International Journal on Food System Dynamics, vol. 3 , No. 1, Bonn, University of Bonn [online] http://centmapress.ilb. uni-bonn.de/ojs/index.php/fsd/article/viewArticle/203.

Djolov, G. (2011), "The Hirschman-Herfindahl Index Reconsidered: Is there a Gini in the Bottle?", 20th EDAMBA Summer Research Academy, Sorèze, France.

Durán Lima, J.E. and M. Álvarez (2008), "Indicadores de comercio exterior y política comercial: Mediciones de posición y dinamismo comercial", Projects Documents, No. 217, Santiago, Chile, Economic Commission for Latin America and the Caribbean (ECLAC)

Dussel, E. (2001), "Un análisis de la competitividad de las exportaciones de prendas de vestir de Centroamérica utilizando los programas y la metodología CAN y MAGIC", Estudios y Perspectivas series, No. 1 (LC/L.1520-P), Mexico City, ECLAC sugregional headquarters in Mexico, July [online] http://www.econbiz.de/en/ search/detailed-view/doc/all/an\%C3\%A1lisis-competitividadlas-exportaciones-prendas-vestir-centroam\%C3\% A9ricautilizando-los-programas-metodolog\% $3 \% \mathrm{ADa}$-can-magicdussel-peters-enrique/10001633811/?no_cache $=1$.
Fadzlan, S. and S. Muzafar (2013), "Financial sector consolidation and competition in Malaysia: an application of the Panzar-Rosse method", Journal of Economic Studies, vol. 40, No. 3, Emerald Group Publishing Limited.

Gower, J. (1971), "A general coefficient of similarity and some of its properties", Biometrics, vol. 27, No. 4, Washington, D.C., International Biometric Society.

(1967), "A comparison of some methods of cluster analysis", Biometrics, vol. 23, No. 4, Washington, D.C., International Biometric Society.

Hirschman, A.O. (1964), "The paternity of an index", American Economic Review, vol. 54, No. 5, Nashville, Tennessee, American Economic Association.

Illescas, J. and C.F. Jaramillo (2011), "Export growth and diversification: the case of Peru", Policy Research Working Paper, No. 5868, Washington, D.C., World Bank, November [online] http://www-wds.worldbank.org/servlet/WDSContentServer/ WDSP/IB/2011/11/01/000158349_20111101083747/Rendered/ PDF/WPS5868.pdf.

Jijena, R. (2003), "Las ondas largas en economía (ciclos Kondratiev) y la emergencia de un nuevo paradigma tecno-económico en Freeman y Louca", Barcelona, Open University of Catalonia, unpublished.

Mariscal, J. and R. Rivera (2007), "Regulación y competencia en las telecomunicaciones mexicanas", Estudios y Perspectivas series, No. 83 (LC/MEX/L.780), Mexico City, ECLAC subregional headquarters in Mexico, June [online] http://www.eclac.org/ publicaciones/xml/7/29037/Serie\%2083.pdf.

Martínez Sánchez, J.M. (2001), "Las ondas largas de Kondratieff. Filosofía, política y economía", Laberinto, No. 5.

Matesanz, D. and A. Sánchez Díez (2005), "La asociación birregional Unión Europea América Latina: Retórica y realidad del comercio y la inversión", VII World Economy Meeting, Madrid, Complutense University of Madrid.

Petit, L. (2012), "The economic detection instrument of the Netherlands Competition Authority: the competition index", NMa Working Paper, No. 6, Netherlands Competition Authority [online] http://ssrn.com/abstract=1992774.

Ponce, M., M. Contreras and M. Vásquez (2007), "Exportación de madera aserrada de conífera chilena. Un análisis de competitividad", Maderas: Ciencia y Tecnología, vol. 9, No. 1, Concepción, Bio-Bio University.

Romo Murillo, R. (2007), "La competitividad exportadora de los sectores ambientalmente sensibles y la construcción de un patrón exportador sustentable en América Latina y el Caribe", Mexico City, June [online] http://www.cepal. org/dmaah/noticias/paginas/1/27731/romo_competitividad _IAS.pdf.

Sánchez Díez, A. and M.L. Villalobos Álvarez (2010), "El análisis de las relaciones comerciales de Centroamérica y la Unión Europea desde una perspectiva de economía política", Santiago de Compostela, May.

Sawaya Jank, M., M.F. Paes Leme and A. Meloni Nassar (2001), "Concentration and internationalization of Brazilian agribusiness exporters", International Food and Agribusiness Management Review, vol. 2, No. 3-4, Amsterdam, Elsevier. 
Schumpeter, J. (1935), "The Analysis of Economic Change", Review of Economics and Statistics, No. 17, pp. 2-10.

Serlin, J. (2010), "Conocimiento de la gestión de las organizaciones: Sistemas complejos dinámicos inestables adaptativos”, thesis, Buenos Aires, Faculty of Economic Sciences, University of Buenos Aires [online] http://www.econ.uba.ar/www/servicios/ Biblioteca/bibliotecadigital/bd/tesis_doc/serlin.pdf.pdf.

Shimizu, T. (2009), "Structural changes in asparagus. Production and exports from Peru", IDE Discussion Paper, No. 201, Tokyo,
Institute of Developing Economies [online] http://ir.ide.go.jp/ dspace/bitstream/2344/843/1/201_shimizu.pdf.

Spilzinger, A.L. (2004), "Adaptación frente a la complejidad: Nuevo paradigma gerencial", Revista VenEconomía, vol. 21, No. 8, May.

Toro, L.A. and J.A. Ruiz (2005), "Efectos potenciales de la inserción comercial de Venezuela en el ALCA", Venezuela en el ALCA: Entre realidades y fantasías, Merida, University of the Andes [online] http://www.mpl.ird.fr/crea/pdf/Libro\%20-\%20ALCA\%20-\%20 Venezuela.pdf. 